\title{
Myeloma Bone Disease: Update on Pathogenesis and Novel Treatment Strategies
}

\author{
Sonia Vallet ${ }^{1, *}$, Julia-Marie Filzmoser ${ }^{2}$, Martin Pecherstorfer ${ }^{1}$ \\ and Klaus Podar ${ }^{1}$ \\ 1 Department of Internal Medicine, Karl Landsteiner University of Health Sciences, University Hospital, \\ 3500 Krems an der Donau, Austria; martin.pecherstorfer@krems.lknoe.at (M.P.); \\ klaus.podar@krems.lknoe.at (K.P.) \\ 2 Karl Landsteiner University of Health Sciences, 3500 Krems an der Donau, Austria; 16KL100042@edu.kl.ac.at \\ * Correspondence: sonia.vallet@krems.lknoe.at; Tel.: +43-(0)-2732-9004-2555
}

Received: 6 September 2018; Accepted: 20 October 2018; Published: 24 October 2018

check for updates

\begin{abstract}
Bone disease, including osteolytic lesions and/or osteoporosis, is a common feature of multiple myeloma (MM). The consequences of skeletal involvement are severe pain, spinal cord compressions, and bone fractures, which have a dramatic impact on patients' quality of life and, ultimately, survival. During the past few years, several landmark studies significantly enhanced our insight into MM bone disease (MBD) by identifying molecular mechanisms leading to increased bone resorption due to osteoclast activation, and decreased bone formation by osteoblast inhibition. Bisphosphonates were the mainstay to prevent skeletal-related events in MM for almost two decades. Excitingly, the most recent approval of the receptor activator of NF-kappa B ligand (RANKL) inhibitor, denosumab, expanded treatment options for MBD, for patients with compromised renal function, in particular. In addition, several other bone-targeting agents, including bone anabolic drugs, are currently in preclinical and early clinical assessment. This review summarizes our up-to-date knowledge on the pathogenesis of MBD and discusses novel state-of-the-art treatment strategies that are likely to enter clinical practice in the near future.
\end{abstract}

Keywords: multiple myeloma; osteolytic bone disease; denosumab; bisphosphonates; Wnt inhibitors

\section{Introduction}

Multiple myeloma (MM) is the second most common hematological malignancy in adults with a median age of diagnosis of approximately 70 years. It accounts for $1 \%$ of all cancers, with a yearly mortality rate of $4.1 / 100,000$ [1]. MM is characterized by bone marrow (BM) plasmacytosis and monoclonal protein in the blood and/or urine. Active myeloma is defined by the presence of one or more of the CRAB criteria-hypercalcemia (calcium $>11 \mathrm{mg} / \mathrm{dL}$ ), renal insufficiency (creatinine $>2 \mathrm{mg} / \mathrm{dL}$ ), anemia (hemoglobin $<10 \mathrm{mg} / \mathrm{dL}$ ), and bone lesions $(\geq 1$ lesion on skeletal survey-determined using computed tomography (CT) or positron emission tomography (PET). In the absence of CRAB features, one or more of the following MM defining events is needed: plasma cell (PC) infiltration of $\geq 60 \%$ of the $B M$, free light chain ratio $\geq 100$, and $\geq 1$ magnetic resonance imaging (MRI) lesion $\geq 5 \mathrm{~mm}$ in size. These symptoms and signs are absent in premalignant stages of MM, including monoclonal gammopathy of undetermined significance (MGUS) and smouldering myeloma (SMM) [2].

Bone disease, comprising osteolytic lesions and/or diffuse osteopenia, is a common feature of MM. It occurs in up to $80 \%$ of patients and persists even in the absence of active disease, since complete repair of bone lytic lesions rarely occurs [3-5]. Indeed, MM is the malignancy with the highest percentage of metastatic bone disease. Myeloma bone disease (MBD) predominantly affects the axial 
skeleton (vertebrae (33\%), ribs (15\%), and sternum (13\%)). MBD may lead to serious complications or skeletal-related events (SREs), defined as spinal cord compression, fractures, hypercalcemia, and the need for palliative surgery or radiation. As a result, patients' quality of life is reduced due to severe pain, psychological distress, and loss of autonomy [6]. In addition, SREs are associated with a significant increase in mortality in MM patients [7,8].

MBD relies on an unbalanced bone remodeling, elicited by increased bone resorption mediated by osteoclasts (OC), and typically reduced bone formation due to the downregulation of the number of functional osteoblasts (OB) [9]. Functionally, MM cells interfere with physiologic bone remodeling by releasing OC-promoting cytokines such as receptor activator of NF-kappa B ligand (RANKL), interleukin (IL)-1, IL-6, chemokine C-C motif ligand 3 (CCL3), and CCL20. Moreover, MM cells are also responsible for the inhibition of osteogenesis, as they upregulate OB inhibitors including dickkopf-1 (DKK1) and sclerostin [10].

Imaging techniques to detect bone lesions significantly improved over the past few years. Compared to conventional skeletal survey (CSS), cross-sectional imaging methods, such as CT, MRI, and more recently fluoro-deoxyglucose (18 F-FDG) PET, allow for improved detection rate of bone lesions [11]. In a recent study, whole-body low-dose CT (WBLDCT) could detect lytic lesions in more than $25 \%$ of patients with negative CSS, leading to upstaging and changes in treatment plan [12]. In contrast to $\mathrm{CT}$, MRI identifies bone marrow lesions without lytic reaction and effectively visualizes soft tissue masses extending from the bone. WBLDCT and MRI, therefore, replaced skeletal survey in the diagnosis and monitoring of MM and MBD in many institutions. Due to its ability to distinguish between metabolically active and inactive lesions, FDG PET is the preferred imaging modality to assess treatment response [13].

Therapeutic strategies, which target pathophysiologic interactions between MM cells, OCs, and $\mathrm{OBs}$ in the BM microenvironment, are crucial to delay the occurrence of SREs, to prevent bone lesions, and to attain tumor regression. Bisphosphonates (BP) and the recently approved RANKL inhibitor, denosumab, are bone-modifying agents (BMA) with anti-catabolic properties recommended for the treatment of MBD [14]. Other potential therapeutic targets include DKK1 and sclerostin antagonists [15]. In addition, classic anti-MM agents such as proteasome inhibitors (bortezomib and carfilzomib) and immunomodulatory drugs (IMiDs) have also an impact on lytic bone lesions by removing the driving force for MBD and by means of their anabolic and anti-catabolic properties, respectively.

Here, we summarize our current knowledge of MBD pathogenesis and its clinical management, with a special focus on the efficacy of BP and denosumab in preventing SREs and inhibiting MM proliferation, survival, and drug resistance. In addition, potential future therapeutic strategies for MBD are discussed.

\section{Pathogenesis of Osteolytic Bone Disease in MM}

\subsection{Physiologic Bone Remodeling}

The bone is a dynamic organ granting support and movement to the human body, and it is actively involved in hematopoiesis and endocrine functions. Bones are characterized by an elaborated network of marrow spaces and blood vessels within a matrix of hydroxyapatite and collagen, giving home to a heterogeneous cell population (bone cells, immune and endothelial cells, and mesenchymal and hematopoietic stem cells) [16]. The skeleton undergoes remodeling, a lifelong dynamic process of bone resorption and formation important to sustain the mechanical load, to preserve bone integrity and to maintain mineral homeostasis. Bone remodeling takes place in the basic multicellular unit (BMU), where OCs, OBs, and osteocytes work in a concerted and coordinated fashion. OCs and OBs are derived from different cellular lineages and possess opposite functions within the bone remodeling cascade [17]. 
OCs derive from the fusion of mononuclear cells of the monocyte-macrophage lineage into multinucleated active cells. They degrade the inorganic and organic bone matrix by binding tightly to the bone surface (sealing zone) and creating an acidic microenvironment rich in proteases (cathepsin and metalloproteinase) [18]. RANK, its ligand RANKL, and the decoy receptor osteoprotegerin (OPG) are considered key factors in regulating OC differentiation and activity [19].

OBs evolve from mesenchymal cells to osteocytes or bone-lining cells by going through specific differentiation steps modulated by time-dependent expression of transcription factors, such as Runt-related transcription factor 2 (RUNX2), Distal-Less Homeobox 5 (DLX5), and osterix, in a process called osteoblastogenesis [20]. Osteoblastogenesis depends on the balanced activity of agonists and antagonists of the Wnt signaling pathway, which regulates the expression of the transcription factor $\beta$-catenin. OBs secrete collagen and other extracellular structural as well as hormone proteins, such as osteopontin and osteocalcin, and they mineralize the bone matrix, thereby inducing bone formation [21]. They ultimately become bone-lining cells, inactive OBs laying on the bone surface; osteocytes, which are embedded in the mineralized matrix; or they undergo apoptosis. Osteocytes detect microcracks, mechanical strains, and changes in the hormonal milieu of the bone, and thus, trigger bone remodeling. Indeed, they play a key role in controlling the osteoclastic and osteoblastic activity, partly by secreting paracrine regulators of the remodeling process such as RANKL and the Wnt inhibitor sclerostin [22,23].

Changes in bone remodeling may be monitored by the detection of specific serum markers, including carboxy-terminal telopeptide of type- 1 collagen (ICTP), $\beta$-crosslaps (CTX), and deoxypyridinoline (DPD), characteristic of bone degradation, as well as bone-specific alkaline phosphatase (BAP), osteocalcin, amino terminal pro-peptide of type I collagen (PINP), and carboxy terminal pro-peptide of type I collagen (PICP), characteristic of bone formation. Importantly, bone markers are also useful to monitor antiresorptive therapies and may help assessing fracture risk [24].

\subsection{The Bone Niche in $M M$}

Malignant plasma cells are home to the BM, whose cellular and extracellular microenvironments promote cell survival, tumor growth, and drug resistance, ultimately leading to MM progression and refractory disease. The cellular elements of the myeloma bone niche comprise bone marrow stromal cells (BMSCs), cells of the OB lineage, OCs, adipocytes, lymphocytes, and endothelial cells. Extracellular elements include the liquid milieu (growth factors, cytokines, and exosomes) and extracellular matrix (ECM) proteins such as osteopontin, collagen, and fibronectin.

Compared to normal cells, BMSCs of MM patients produce higher amounts of cytokines, such as IL-6, and induce T-lymphocyte dysfunction [25]. BMSCs modulate proliferation, migration, and drug resistance of MM cells also by releasing exosomes, small membranous vesicles that transfer oncogenic proteins, cytokines, messenger RNAs (mRNAs), and microRNAs to malignant plasma cells [26-28]. Integrin-mediated adhesion to BMSCs, as well as BMSC-secreted cytokines, stimulates tumor cell growth [29], at least, in part, via activation of the JunB transcription factor as recently shown [30]. Similarly, OCs provide proliferative and survival advantage to malignant plasma cells [31], in contrast to OBs that suppress tumor cell growth at least partly via the expression of decorin [32,33]. Interestingly, a recent study of the Croucher group suggests that OCs and OBs regulate cell dormancy and reactivation. Specifically, MM cells enter a quiescent non-mitotic state by interacting with bone-lining cells, whereas bone resorption induces MM cell proliferation [34].

Osteocytes and adipocytes play an emerging role as MM-promoting cells in the bone niche. Osteocytes induce MM cell growth via direct activation of the Notch signaling pathway as well as increase in Notch receptor expression [35]. Adipocytes, which are increased in the BM of MM patients, stimulate the proliferation and mediate the drug resistance of malignant plasma cells via secretion of adipokines, such as leptin and resistin. In addition, pre-adipocytes promote migration of MM cells [36-39].

In addition, immune cells, such as T lymphocytes, natural killer (NK) cells, and dendritic cells, populate the bone milieu. They are functionally defective in MM patients compared to healthy individuals and contribute to the immune escape of MM cells [40]. Moreover, the cluster of differentiation 4 (CD4)/CD8 T-cell ratio is decreased and immunosuppressive regulatory $\mathrm{T}$ cells (Tregs) are increased. Dysfunctional NK 
T-cells lack interferon- $\gamma$ secretion $[40,41]$. Interestingly, recent studies demonstrated an upregulation of the pro-inflammatory T helper 17 (Th17) T-cell subset in MM patients, which contributes to the development of osteolytic lesions [42]. NK cell-mediated cytotoxicity is ineffective against MM cells, due to downregulation of natural cytotoxicity receptors (NCRs) and Natural Killer Group 2D (NKG2D) receptors expression, as well as upregulation of Programmed cell death protein (PD)-1surface levels on NK cells [43-45]. Finally, myeloid and plasmacytoid dendritic cells (DCs) are numerically decreased and functionally impaired in MM, thus further worsening T-cell dysfunction [46].

\subsection{Myeloma-Associated Bone Disease}

In cancer settings, an increase in OC activity disrupts the balance of the bone remodeling process leading to dramatic changes in the bone architecture and to the development of osteolytic lesions. In MM, in particular, effects of the upregulated osteoclastogenesis are amplified by the inhibition of OB activity and the increase in osteocyte apoptosis. In turn, bone cells regulate survival, proliferation, and drug resistance of malignant plasma cells, thus contributing to the vicious cycle of MBD. They also actively participate in engaging and disengaging tumor cells from dormancy and they may facilitate MM escape from the immune system $[31,34,47]$.

Enhanced bone turnover is an early event in plasma cell disorders, also including premalignant diseases such as MGUS [48]. However, studies on bone biopsies from MGUS patients demonstrate regular OB activation for a balanced bone remodeling, whereas, in active MM, OC and OB activity is uncoupled with consequent disruption of the bone balance $[49,50]$. These pathogenetic events translate to changes in bone biomarkers, with an increase in parameters of bone resorption and suppression of bone formation markers detected in MM patients. By monitoring changes in the serum levels of markers of bone turnover, such as CTX and PINP, it is possible to detect disease progression and maybe select patients at risk of developing active MM [51,52].

Functionally, the increase in bone resorption in MM is due to an upregulation of signaling factors that promote OC differentiation and function, namely RANKL, chemokines (CCL3), and interleukins (IL-6). MM-derived exosomes, either from cell line or patient sera, also stimulate migration, survival, and differentiation of OC precursor cells [53]. In addition, tumor cells modify the surrounding microenvironment toward the inhibition of osteogenesis, by directly secreting Wnt antagonists such as DKK1 or by inducing the release of OB inhibitors from mesenchymal cells and osteocytes, such as sclerostin and activin. Indeed, recent studies suggest a key role for osteocytes in the development of MBD. The number of viable osteocytes is reduced in MM patients, especially in the presence of bone lesions due to increased apoptosis, and correlates with OC number [54]. Apoptotic osteocytes express high levels of RANKL and sclerostin, thus enhancing their ability to attract OC precursors and to inhibit OB differentiation (Figure 1) [35].

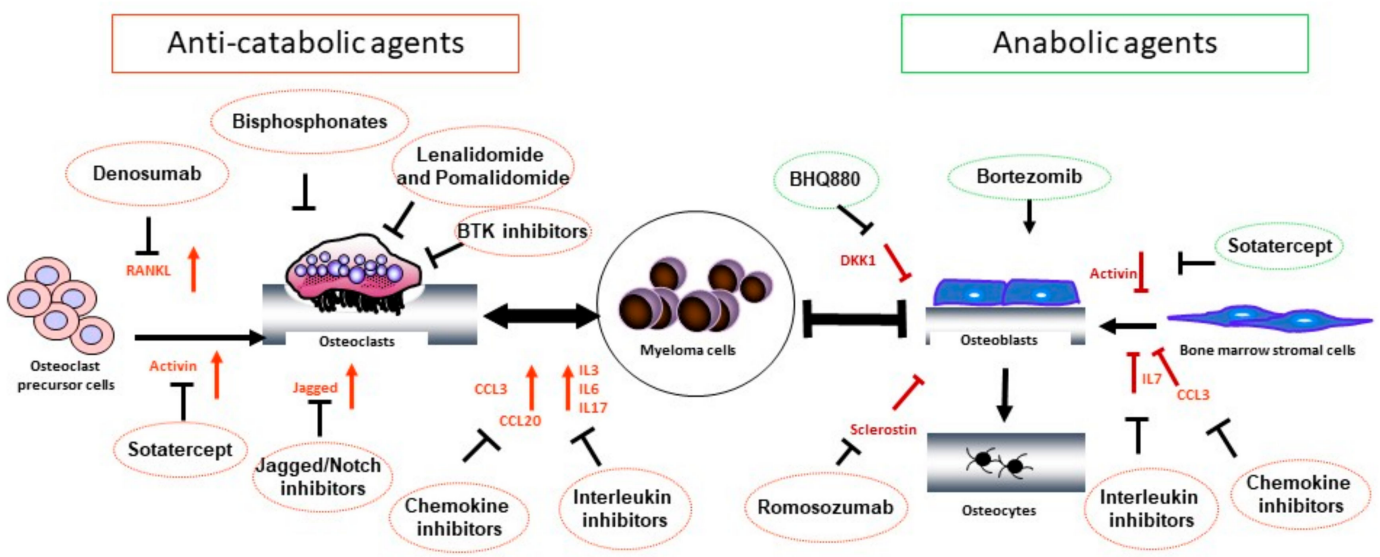

Figure 1. Schematic representations of the main signaling pathways involved in the pathogenesis of myeloma bone disease and their inhibitors. 
Malignant plasma cells modify their microenvironment by directly secreting and, indirectly, by stimulating the release of cytokines, which regulate osteoclastogenesis and osteoblastogenesis. Osteoclast-activating cytokines include RANKL, IL-3, IL-6, IL-17, CCL3, and CLL20. OB inhibition is mediated by MM-derived DKK1 and CCL3, as well as by BMSC-derived activin A and osteocyte-derived sclerostin. Importantly, MM cells also increase the RANKL/OPG ratio by stimulating osteocyte secretion of RANKL and inhibiting BMSC release of OPG. As a result of these complex interactions, the bone remodeling balance is disrupted and osteolytic lesions develop.

\subsubsection{Signaling Pathways Stimulating OC Activity in MM}

\section{RANK/RANKL Pathway}

The RANK/RANKL pathway belongs to the most relevant physiologic and therapeutic signaling pathways for the regulation of bone resorption. RANK is a receptor of the tumor necrosis factor (TNF) superfamily, expressed on the surface of OC precursors. RANK ligand (RANKL) is the associated cytokine, secreted predominantly by osteocytes and, to a lesser extent, by BMSC and OBs [22]. By binding to RANK on immature OCs, RANKL induces their differentiation into mature cells [55]. OPG is a decoy receptor of the TNF superfamily, which also binds to RANKL. OPG is secreted by OBs and acts as a RANKL antagonist, thus inhibiting osteoclastogenesis.

In MBD, malignant plasma cells directly secrete RANKL and also stimulate its release via by $\mathrm{T}$ lymphocytes and osteocytes in the bone niche [56]. Specifically, MM cells induce osteocyte apoptosis via activation of Notch signaling, and apoptotic osteocytes express high levels of RANKL [35,54]. In addition, interactions of MM cells with the BM microenvironment lead to upregulation of different cytokines (IL-1 and TNF- $\alpha$ ) and hormones (parathyroid hormone-related protein), which induce RANKL and decrease OPG expression, resulting in an increase of OC activity and bone destruction. Due to the critical role of OCs in MBD, suppression of OC maturation via RANKL blockade not only decreases bone resorption, but also inhibits tumor development in preclinical models of MM [57]. These data highlight the therapeutic relevance of targeting RANKL signaling in MM.

\section{Notch/Jagged Pathway}

The canonical Notch pathway includes four receptors (Notch 1-4) and five ligands (Delta-like (DLL)1, 3-4, and Jagged 1-2). Following ligand binding, the intracellular domain of the receptor is released via protease (Tumor necrosis factor-alpha-converting enzyme (TACE/ADAM) and $\gamma$-secretase)-mediated cleavage and translocates to the nucleus to interact with several transcriptional factors [58,59]. Physiologic activation of the Notch/Jagged pathway regulates the survival of hematopoietic stem cells in the bone microenvironment partly via activation of the c-MYC transcription factor. Its aberrant activation contributes to the development of hematologic malignancies, and is critical for the progression and chemoresistance of MM [60]. Notch/Jagged signaling is also involved in osteolytic bone destruction via RANK/RANKL activation. By activating Notch on malignant plasma cells and OC precursor cells, BMSCs and MM cell-derived Jagged ligands stimulate RANKL expression in an autocrine and paracrine loop. In turn, RANK activation upregulates Notch 2 gene expression in OC precursors, thus potentiating RANKL signaling. Interestingly, Notch activation in osteocytes stimulates RANKL expression and increases the RANKL/OPG ratio. Due to its widespread expression in the MM microenvironment and its regulatory role on the RANK/RANKL pathway, Notch is a promising target in MM treatment [35,61].

\section{Chemokines}

Chemokines are small cytokines regulating cell migration during immune response and angiogenesis. In addition, they play an important role in the pathogenesis of MBD.

Chemokine (C-C motif) ligand 3 (CCL3), also known as macrophage inflammatory protein (MIP) $1-\alpha$, is a pro-inflammatory cytokine secreted by MM cells and promotes autocrine migration and 
adhesion via binding to different receptors (such as chemokine $\mathrm{C}-\mathrm{C}$ motif receptor 1 (CCR1) and CCR5). CCL3 is a strong osteoclastogenic factor, which promotes cell-cell fusion to form multinucleated OCs and stimulate RANKL expression by BMSCs [62-64]. Levels of CCL3 correlate with the extent of bone disease and bone resorption markers in MM [65].

CCL20 (MIP-3 $\alpha)$ is a chemokine involved in the recruitment of T helper 17 (Th17) cells during inflammation and is also implicated in MM osteolytic disease. CCL20 is secreted by BMSCs, OBs, and OCs upon stimulation by MM cells, which also induce expression of its receptor CCR6 on OCs. Similar to CCL3, CCL20 induces osteoclastogenesis by increasing the number of precursor cells [66]. Levels of CCL20 correlate with the extent of MBD [66,67].

TNF- $\alpha$ is a proinflammatory cytokine involved in physiologic and pathologic processes, including rheumatoid arthritis and cancers. It promotes survival of MM cells by activating the nuclear factor kappa B (NF-kB) signaling pathway and by stimulating autocrine IL-6 production, and induces MM cell migration via upregulation of monocyte chemoattractant protein (MCP)-1 in tumor cells [68]. In addition, TNF- $\alpha$ acts synergistically with RANKL to stimulate osteoclastogenesis and inhibits OB differentiation by downregulating osterix transcription $[69,70]$.

\section{Interleukins}

Interleukins are cytokines involved in immune regulation, inflammatory response, and hematopoiesis. In MM, several interleukins, such as IL-6, IL-3, IL-17, IL-1, and IL-11, regulate cell proliferation, survival, and drug resistance, and promote osteolytic lesions, thus underscoring the pathogenetic role of the deregulated immune system in MM.

IL-6 is secreted by BMSCs and OCs. In addition to representing a key survival factor for malignant plasma cells, it directly enhances OC differentiation and activation by binding to its receptor on OC precursor cells, and indirectly by upregulating osteopontin and vascular endothelial growth factor (VEGF) expression [71]. IL-3 derives from activated lymphocytes and stimulates CCL3 and RANKL-induced osteoclastogenesis and bone resorption. In addition, it induces activin A production, leading to increased osteoclastogenesis and decreased osteogenesis [72-74]. IL-17 expressed by $\mathrm{T}$ helper 17 lymphocytes has pro-osteoclastogenic properties. Of note, its levels correlate with the extent of bone disease in MM [75].

Similar effects on bone resorption and formation were described for IL-11 and IL-1 $\beta$ [76,77]. Interestingly, IL-11 expression in osteocytes of MM patients is higher than in healthy donors, correlating with the OC number [54].

\subsubsection{Signaling Pathways Suppressing OB Activity in MM}

Canonical and Non-Canonical Wnt Pathways

The Wnt signaling pathway is important for several physiologic processes like embryogenesis, organ formation, bone remodeling, and insulin sensitivity. Canonical Wnt signaling is mediated by the transcription factor $\beta$-catenin. Briefly, in the absence of Wnt signaling, $\beta$-catenin is bound to a complex mediating its degradation by ubiquitination. However, by binding to the receptor Frizzled and co-receptor lipoprotein receptor-related protein (LRP)-5/6, Wnt activates Dishevelled (Dsh) which releases $\beta$-catenin from the destruction complex and allows it to translocate into the nucleus and initiate transcription [78-80].

Aberrant Wnt signaling was described in MM, where it is responsible for MM cell proliferation, migration, and adhesion-mediated drug resistance [81]. In addition, inhibitors of the canonical Wnt pathway such as sclerostin, DKK1, and secreted Frizzled-related protein (sFRP)2/3 are elevated in $\mathrm{MM}$ and inhibit bone formation by preventing $\beta$-catenin signaling $[63,82,83]$.

Sclerostin is a glycoprotein produced by osteocytes in response to mechanical strain of the body. The lower the mechanical strain is, the higher the sclerostin secretion becomes. Sclerostin binds to LRP4, which acts as a chaperone presenting sclerostin to the Wnt co-receptors LRP5/6, thus facilitating 
inhibition of Wnt/ $\beta$ catenin signaling $[84,85]$. Ultimately, sclerostin impairs OB differentiation and bone mineralization; it also induces apoptosis of mature OBs by caspase activation, and stimulates osteoclastogenesis by increasing the RANKL/OPG ratio [23,86]. MM cells induce osteocyte apoptosis, which correlates with increased expression of RANKL and sclerostin [35]. Indeed, increased levels of sclerostin are demonstrated in MM patients with evidence of bone fractures at diagnosis $[83,87]$.

DKK1 is another antagonist of the Wnt signaling pathway secreted by MM cells [88]. By binding to LRP6, it inhibits osteoblastogenesis and new bone formation. DKK1 is also responsible for enhanced sclerostin secretion in the bone microenvironment, since sclerostin is released by immature OBs in the presence of MM-derived DKK1 [83]. Moreover, DKK1 increases the RANKL/OPG ratio, which stimulates osteoclastogenesis. Interestingly, inhibition of Wnt signaling increases the secretion of IL-6 that stimulates proliferation of MM cells, and thus, enhances DKK1 release in a vicious cycle [89]. High DKK1 gene expression levels correlate with MBD and may predict for SRE development in MM patients undergoing bisphosphonate treatment [82,90].

MM cells also inhibit osteogenic differentiation of BMSCs by interfering with the non-canonical Wnt5a signaling pathway. Specifically, they reduce the expression of the co-receptor Ror2 in preOBs, thus preventing their differentiation in mature cells [91].

\section{Activin A}

Activin A is a member of the transforming growth factor beta (TGF- $\beta$ ) family of proteins produced by many cell types throughout development. It signals through SMAD2/3 proteins to regulate a variety of functions, including cell proliferation, differentiation, apoptosis, wound healing, and metabolism.

In MM patients, elevated serum levels of activin A correlate with lytic bone lesions and advanced disease stage. Indeed, activin A inhibits OB differentiation and promotes osteoclastogenesis in MM. Malignant plasma cells upregulate activin A secretion by BMSCs. It exerts its inhibitory effects on OBs by downregulating the transcription factor DLX5 in precursor cells of the OB-lineage [92]. In addition, activin A promotes OC differentiation via non-canonical signaling, namely activation of the NF- $\mathrm{kB}$ pathway in a RANKL-independent fashion [93].

\section{Chemokines and Interleukins}

As soluble inhibitors of osteogenesis in MM, IL-7 and CCL3 contribute to the development of MBD. MM-derived IL-7 is responsible for the inhibition of OB formation via RUNX2 downregulation [94]. CCL3, in addition to its osteoclastogenic activity, represses OB function via osterix downregulation. An early increase in CCL3 levels was detected in animal models of MM, and they correlated with reduced mineralization and bone formation at early time points, despite normal OB counts $[95,96]$.

\section{Treatment of Osteolytic Bone Disease in MM}

Treatment of MBD relies on the use of BMAs, which alleviate the complications of skeletal lesions and reduce the occurrence of SREs. Bisphosphonates represented, until recently, the standard of care for MBD. Importantly, in January 2018, the anti-RANKL antibody, denosumab, was approved in MM for the same indications as BPs. Both agents inhibit bone resorption by targeting OCs and differ mainly in terms of their impact on renal function [97]. Based on the recent progress of our understanding of the MBD pathogenesis, several new agents with a broad range of mechanisms of actions are under development. Importantly, classic anti-MM agents, proteasome inhibitors, and IMiDs also show effects on the bone, and combination strategies of MM- and bone-targeting compounds represent a promising treatment approach in active MM (Figure 1) [10,15,98].

\subsection{Bisphosphonates}

As derivates of pyrophosphates, BPs tightly bind to hydroxyapatite crystals in the bone, where they are absorbed by OCs. They exert their anti-catabolic effect by inhibiting OC formation and differentiation, as well as by inducing OC apoptosis. BPs not retained in the skeleton are rapidly cleared 
from circulation by renal excretion. Importantly, they also display anti-tumor and immunomodulatory activity [99]. Their chemical structure correlates with their strength: nitrogen-containing BP, like pamidronate (PAM) or zoledronic acid (ZOL), are 100 to 10,000 times more potent compared to non-nitrogen containing BP (such as clodronate) [100].

The most widely used BPs in MM are PAM and ZOL, both approved as monthly intravenous administration for patients with active MM, either with lytic lesions or with osteoporosis in the absence of osteolysis. PAM and ZOL show comparable effects in reducing the incidence of SREs, and they are more effective than oral agents such as clodronate (CLO) for SRE prevention. Importantly, based on the results of the Medical Research Council (MRC) Myeloma IX trial, ZOL not only significantly prevents SREs in MM patients with and without lytic bone disease, but also improves progression-free, as well as overall, survival compared to CLO [101]. BPs are also recommended for pain control resulting from osteolysis or in fracture management as adjunctive treatment to radiotherapy, surgery, and analgesics. Additional indications for BPs include the presence of osteoporosis in low- and intermediate-risk asymptomatic MM or in MGUS.

The main side effects of BPs are renal toxicity and osteonecrosis of the jaw (ONJ); therefore, patients undergoing long-term treatment should be closely monitored. PAM induces glomerular lesions, while ZOL induces acute tubular necrosis, both associated with acute renal failure [102]. Regular surveillance of serum creatinine and urinary proteins is, thus, important during treatment [103]. ONJ is a potentially serious condition affecting $1-10 \%$ of the patients in long-term treatment, with higher incidence with ZOL than PAM (10\% versus $4 \%$ ). ONJ in patients receiving BPs is defined by the presence of exposed bone in the jaw lasting for more than eight weeks, despite proper dental management. Severity and symptoms are variable; some patients experience pain and fistulae, whereas a few may even remain asymptomatic. Risk factors for ONJ are tooth extraction or other invasive dental surgeries, long duration of BP therapy, poor oral hygiene, and older age. To prevent ONJ all patients should receive dental review and appropriate treatments before starting BP therapy [104]. Rare complications associated with long-term BP use are atypical fractures of the femoral shaft, which occur with minimal trauma and predominantly affect young patients $[105,106]$. They may result from BP-mediated suppression of bone remodeling, leading to accumulation of microdamages and impaired damage repair $[107,108]$.

Due to long-term toxicity, BP treatment should be limited to two years for MM patients in remission. In addition, a three-monthly schedule should be considered for patients with stable disease or on maintenance therapy. Indeed, the bone-marker-directed ZOL administration evaluated in the recent Zoledronic Acid - Bone MARKer-Directed Dosing (Z-MARK) study shows that less frequent ZOL dosing (every 12 weeks over two years) is associated with two-year ONJ incidence of 3.3\%, while maintaining a low SRE rate (Table 1) [109].

\subsection{Denosumab}

RANKL is a key player in the pathogenesis of MBD, and its inhibition via the monoclonal anti-RANKL antibody, denosumab, is an effective treatment strategy in MM. Denosumab binds to RANKL with high affinity and specificity; it inhibits its interaction with RANK and results in supressed bone resorption [110]. Phase 1 clinical trials showed that single and multiple applications of denosumab in healthy postmenopausal women led to sustained suppression of OC-mediated bone resorption [111]. In phase 2 studies in solid cancers and advanced MM, denosumab resulted in a significant inhibition of SREs [112,113]. Denosumab was approved for the treatment of osteoporosis as twice yearly subcutaneous applications, and for bone metastases in solid cancers as monthly injections in 2010 .

The efficacy of denosumab compared to ZOL in MM patients was evaluated in two large randomized phase 3 clinical trials. The "244" study enrolled more than 1700 patients with solid cancers (except breast and prostate cancers) and MM. It demonstrated the superiority of denosumab compared to ZOL in terms of time to first on-study SRE (20.6 versus 16.3 months), with a comparable 
toxicity profile. Interestingly, the overall survival data in the MM subgroup (300 patients) were inferior in the denosumab arm compared to the ZOL arm [114]. The unbalance in baseline variables (lower Eastern Cooperative Oncology Group (ECOG) performance status and International Staging System (ISS) stage in the ZOL group) and treatment strategies (less transplantation in the denosumab arm) may at least, in part, explain the observed difference in survival [115]. A follow-up study enrolling only MM patients stratified for therapy and ISS stage was, therefore, launched. The " 482 " study included 1718 patients, 1:1 randomized to denosumab or ZOL. The primary endpoint of non-inferiority to ZOL for time to first SRE was met. Grade 3 adverse events and ONJ incidence were infrequent and similar between treatment arms. Renal toxicity was reported in $10 \%$ of patients in the denosumab group versus $17 \%$ in the ZOL group; hypocalcemia was more frequent in the denosumab arm (17\% versus $12 \%$ ) [14]. Intriguingly, preliminary data suggest a progression-free survival advantage for denosumab compared to ZOL; further studies to confirm these results are ongoing (Table 1) [116].

Based on the results of this study denosumab was approved in January 2018 for the treatment of MM patients with active disease and as additional pain control management in the case of lytic lesions or fractures. Treatment recommendations to prevent ONJ do not differ from BPs. Due to the favorable renal toxicity profile, denosumab is recommended in patients with compromised renal function. As for treatment duration of denosumab therapy, there are no specific recommendations; caution is advised in the case of abrupt treatment interruptions, since denosumab has a reversible mechanism of action.

Table 1. Zoledronate and denosumab in myeloma bone disease.

\begin{tabular}{|c|c|c|}
\hline & Zoledronate & Denosumab \\
\hline Agent & Nitrogen-containing bisphosphonate & $\begin{array}{l}\text { Fully human anti-RANKL IgG2 monoclonal } \\
\text { antibody }\end{array}$ \\
\hline Dosing schedule $[97,109]$ & $\begin{array}{l}\text { Renal-adapted, iv administration every } 3-4 \\
\text { weeks or every } 12 \text { weeks }\end{array}$ & sc administration, every 4 weeks \\
\hline Median time to first SRE [14] & 24 months & 22.8 months \\
\hline Median PFS [116] & 35.4 months & 46.1 months \\
\hline Renal toxicity [14] & $17 \%$ & $10 \%$ \\
\hline ONJ [14] & $3 \%$ & $4 \%$ \\
\hline
\end{tabular}

Abbreviations: RANKL, receptor activator of NF-kappa B ligand; IgG2, immunoglobulin G2; iv, intravenous; sc, subcutaneous; SRE, skeletal-related event; PFS, progression-free survival; ONJ, osteonecrosis of the jaw.

\subsection{Anti-Tumor Therapies with Bone-Modifying Effects}

\subsubsection{Proteasome Inhibitors}

Proteasome inhibition emerged as a backbone treatment strategy in MM, exerting its anti-tumor activity directly by promoting cell apoptosis and indirectly by modifying the bone microenvironment [117]. Of note, the proteasome pathway also plays an important role in OB differentiation. Its inhibition by bortezomib stimulates $\mathrm{OB}$ activity and number, partly by upregulating the RUNX2 transcription factor, with a consequent increase in bone formation [118]. In addition, bortezomib inhibits osteoclastogenesis and OC bone resorption activity [119]. In MM patients, bortezomib-based regimens increase the number of RUNX2-positive OBs and lead to a significant 
rise in osteoblastic markers, specifically BAP and osteocalcin [120,121]. Importantly, an increase in bone formation markers is only observed in responding patients and is transient. After reaching a peak in the 6th week of treatment, BAP levels slightly decline [120,122]. Moreover, bortezomib increases the number of viable osteocytes, partly by inhibiting MM-induced autophagy and apoptosis of osteocytes [123].

\subsubsection{Immunomodulatory Agents}

IMiDs, such as lenalidomide and pomalidomide, represent other therapeutic backbones for MM treatment. IMiDs induce MM cell apoptosis, increase anti-MM T- and NK-cell immunity, and inhibit angiogenesis. In vitro studies on pomalidomide and lenalidomide suggest inhibition of osteoclastogenesis via downregulation of PU.1, a key factor for OC differentiation [124,125]. In addition, treatment with IMiDs normalizes the RANKL/OPG ratio in MM [126]. Patients responding to lenalidomide and dexamethasone regimens have a decline in bone resorption markers, but no change in markers of bone formation. On the contrary, adding bortezomib to the combination leads to a decrease in bone resorption and an increase in bone formation markers, independently of treatment response. These effects are at least, in part, due to the normalization of the RANKL/OPG ratio and a reduction in DKK1 levels, respectively [127].

\subsection{Wnt Pathway Modulators}

Despite the key role of $\mathrm{OB}$ suppression in MBD, currently approved treatment strategies have only anti-catabolic properties. The clinically most advanced anabolic strategies involve inhibitors of the Wnt pathway, namely DKK1 and sclerostin antagonists.

Specifically, neutralizing antibodies, such as BHQ880 and MabB3, and DNA-based vaccines were developed to target DKK1 [128-130]. BHQ880 is a fully human immunoglobulin G1 (IgG1) anti-DKK1 antibody, which stimulates $\mathrm{OB}$ differentiation and inhibits myeloma cell growth via alteration of the BM microenvironment [128,131]. A phase 2 clinical trial with high-risk SMM patients demonstrated bone anabolic effects of single agent BHQ880, without significant anti-tumor activity [132]. BHQ880 in combination with ZOL and anti-myeloma treatments was well tolerated and increased bone mineral density in relapsed or refractory MM patients [133].

The main source of DKK1 in MM is malignant plasma cells, and, since not all patients express DKK1, there may be differences in response to anti-DKK1 therapies. In contrast, sclerostin is expressed by osteocytes and its inhibition may be a more effective therapeutic strategy. Treatment with romosozumab, a humanized monoclonal antibody against sclerostin, enhanced bone mineral density in osteoporotic patients, leading to its approval for the treatment of osteoporosis [134]. Preclinical studies in MM showed that genetic inhibition of sclerostin prevents MBD development in early MM models, and anti-sclerostin antibodies reduce osteolysis and increase bone mass in advanced MM models, without having an impact on tumor burden $[83,87,135]$. Since sclerostin inhibition has no significant anti-tumor activity, combination strategies may be critical to achieve anti-MM and bone-protecting effects. Indeed, the combination of anti-sclerostin with the new proteasome inhibitor, carfilzomib, results in tumor burden reduction $[83,136]$.

\subsection{Promising Agents in Preclinical and Early Clinical Development}

Based on pathogenetic studies several new agents are under preclinical and clinical evaluation, among them, inhibitors of activin A, the Notch pathway, chemokines, and interleukins, as well as epigenetic therapies (Table 2).

Inhibition of activin A by a decoy receptor effectively reduced skeletal lesions and decreased tumor burden in animal models of MBD by reversing OB inhibition [92,137]. In a phase 2 clinical trial, treatment of newly diagnosed or relapsed/refractory MM patients with the activin A fusion receptor, sotatercept, in combination with standard chemotherapy (melphalan, dexamethasone, and thalidomide), improved bone mineral density and bone formation compared to placebo. In addition, a 
positive effect on anemia was observed [138]. Interestingly, based on in vitro studies, sotatercept may be effectively combined with lenalidomide, which stimulates activin A secretion via activation of the JNK pathway. The combination demonstrates anabolic and anti-tumor activity in preclinical models of MBD [139].

Anabolic effects were also observed using epigenetic therapies. MM cells induce permanent repressive epigenetic changes at the Runx2 promoter of mesenchymal cells, thus suppressing OB differentiation. Inhibition of Histone deacetylase (HDAC)1 activity in OB precursor cells reverses this effect and rescues osteoblastogenesis [140]. Similarly, the HDAC inhibitor, vorinostat, promotes OB differentiation by upregulating the transcription factor RUNX2. In a murine model of MM, treatment with vorinostat and quisinostat prevents bone loss and development of osteolytic lesions [141,142]. Combination strategies with HDAC inhibitors are currently being evaluated in clinical trials.

Considering the wide range of functions of the Notch signaling pathway in the pathogenesis of $\mathrm{MM}$, its inhibition is considered a promising therapeutic strategy. In addition to reducing MM cell migration and growth, inhibition of Notch via $\gamma$-secretase inhibitor (GSI) XII impairs OC differentiation and demonstrates in vivo anti-MM and anti-catabolic effects [143,144]. Despite the encouraging preclinical data with GSI inhibitors, severe gastrointestinal toxicity caused by simultaneous inhibition of Notch 1 and 2 receptors may preclude their further clinical development [145]. Strategies to mitigate these side effects are based on intermittent dosing schedules and use of glucocorticoids [146]. In addition, antibody-based targeting of Notch receptors or ligands represents a valid alternative to pan-Notch inhibitors, due to their promising anti-tumor activity and better tolerability $[147,148]$.

The promiscuity in ligand-receptor interactions of chemokines is a challenge for their clinical development, since each receptor may have a distinct role in MM pathogenesis. However, preclinical data indicate that CCR1 may be a promising target for MBD [149]. CCR1 inhibition via a small molecule exerts a strong anti-catabolic effect by inhibiting OC formation and function, thus reducing bone osteolytic lesions in animal models [62,150]. In addition, it overcomes CCL3-induced OB inhibition. Animal models further confirmed this dual effect of CCR1 antagonists by demonstrating upregulation of osteocalcin expression along with OC downregulation [95].

Similar inhibitory effects on OCs were shown with an anti-human IL-17A antibody, which additionally impairs MM cell survival [151]. IL-6 is another interesting target. A fully humanized monoclonal antibody against IL-6 (1339) demonstrated anti-tumor activity, as well as inhibition of bone resorption, in mouse models of $\mathrm{MBD}$ as a single agent and synergistic effects with conventional anti-MM agents [152]. Finally, promising agents with anti-MM and bone modifying effects are the inhibitors of the Bruton's tyrosine kinase (BTK). BTK belongs to the B-cell antigen receptor signaling pathway, regulates B-cell development, and participates in the progression of B-cell malignancies. Indeed, BTK inhibitors are approved treatment strategies in lymphoma. Interestingly, the BTK pathway is also activated by RANKL signaling in OCs, and its inhibition by ibrutinib leads to a decrease in OC number and bone resorption activity in vitro and in animal models of MBD [153]. 
Table 2. Agents in early clinical and preclinical development.

\begin{tabular}{|c|c|c|}
\hline Molecular Target & Function & Therapeutic Relevance \\
\hline Jagged/Notch pathway $[35,61]$ & $\begin{array}{l}\text { - Jagged derives from MM cells and BMSC } \\
\text { - Notch activation in tumor cells, OC precursors and } \\
\text { osteocytes stimulates RANKL secretion } \\
\text { - } \begin{array}{l}\text { Notch activation in osteocytes leads to } \\
\text { cell apoptosis }\end{array}\end{array}$ & $\begin{array}{l}\text { - Notch inhibition via } \gamma \text {-secretase inhibitor (GSI) XII } \\
\text { has anti-MM effects and inhibits OC differentiation, } \\
\text { thus improving bone architecture in animals } \\
\text { models of MM }[143,144]\end{array}$ \\
\hline CCL3 (MIP-1 $\alpha$ ) [62-64] & $\begin{array}{l}\text { - } \quad \text { CCL3 is secreted by MM cells } \\
\text { - } \quad \text { It attracts OC precursors inducing } \\
\text { cell multinucleation } \\
\text { - } \quad \text { It stimulates RANKL expression by BMSCs } \\
\text { - CCL3 inhibits OB maturation }\end{array}$ & $\begin{array}{l}\text { - Inhibition of the CCL3 receptor CCR1 has } \\
\text { anti-catabolic effects and stimulates OB activity in } \\
\text { MBD models }[62,95]\end{array}$ \\
\hline CCL20 (MIP-3 $\alpha)$ [66] & $\begin{array}{l}\text { - CCL20 derives from BMSC, OB, and OC in } \\
\text { response to MM cells } \\
\text { - CCL20 stimulates osteoclastogenesis }\end{array}$ & \\
\hline IL-3 [72-74] & $\begin{array}{l}\text { - IL-3 derives from activated lymphocytes } \\
\text { - It amplifies the osteoclastogenic effect of CCL3 } \\
\text { and RANKL } \\
\text { - It induces activin A production }\end{array}$ & \\
\hline IL-17 [75] & $\begin{array}{l}\text { - } \quad \text { IL-17 is expressed by Th17 cells } \\
\text { - It stimulates osteoclastogenesis }\end{array}$ & $\begin{array}{l}\text { Anti-IL17A antibody inhibits OC differentiation, } \\
\text { and decreases tumor growth and bone lesions in } \\
\text { animal models of MM [151] }\end{array}$ \\
\hline IL-7 [94] & $\begin{array}{l}\text { - IL-7 downregulates RUNX2, thus inhibiting } \\
\text { OB differentiation }\end{array}$ & \\
\hline IL-6, IL-1 $\beta$, IL-11 [71,76,77] & $\begin{array}{l}\text { - IL-6, IL-1 } \beta \text {, and IL-11 stimulate OC differentiation } \\
\text { - IL-6 upregulates osteopontin and VEGF expression, } \\
\text { which induce OC activity }\end{array}$ & $\begin{array}{l}\text { - IL-6 mAb (1339) shows anti-tumor activity and } \\
\text { inhibits bone resorption in animal models of MBD } \\
\text { [152] }\end{array}$ \\
\hline DKK1 $[83,88]$ & $\begin{array}{ll}\text { - } & \text { DKK1 is secreted by MM cells } \\
\text { - } & \text { It inhibits OB differentiation } \\
\text { - } & \text { It stimulates secretion of sclerostin and IL-6 } \\
\text { - } & \text { It increases RANKL secretion }\end{array}$ & $\begin{array}{l}\text { DKK1 inhibition stimulates OB differentiation and } \\
\text { reduces IL-6 levels in vitro } \\
\text { - } \quad \text { Anti-DKK1 mAb restore bone formation and inhibit } \\
\text { tumor growth in preclinical models }[128,131] \\
\text { - } \quad \begin{array}{l}\text { BHQ880 has bone anabolic effect alone in } \\
\text { smouldering MM patients [132] }\end{array} \\
\text { BHQ880 in combination with ZOL and anti-MM } \\
\text { therapy increases bone mineral density in MM } \\
\text { patients [133] }\end{array}$ \\
\hline Sclerostin $[23,86]$ & $\begin{array}{l}\text { - Sclerostin derives from osteocytes } \\
\text { - It suppresses osteoblastogenesis and mineralization, } \\
\text { and induces apoptosis of mature OBs } \\
\text { - It increases RANKL/OPG ratio }\end{array}$ & $\begin{array}{l}\text { - Sclerostin inhibition prevents MBD and reduces } \\
\text { osteolysis in preclinical models MM } \\
\text { Sclerostin inhibition in combination with } \\
\text { carfilzomib reduces tumor burden and inhibits } \\
\text { bone disease in animal models of MM [83] }\end{array}$ \\
\hline Activin A $[92,93]$ & $\begin{array}{l}\text { - Activin A is released by BMSCs under MM } \\
\text { cell influence } \\
\text { - It downregulates DLX5 expression in OB precursor, } \\
\text { thus preventing cell differentiation } \\
\text { - It promotes OC differentiation via non-canonical } \\
\text { NF- } \mathrm{kB} \text { pathway activation in precursor cells }\end{array}$ & $\begin{array}{l}\text { - Activin A inhibition via a decoy receptor reverses } \\
\text { bone lesions and decreases tumor burden in MBD } \\
\text { models [92,137] } \\
\text { Activin A inhibition together with lenalidomide } \\
\text { has a strong anti-tumor and anabolic activity in } \\
\text { animal models [139] } \\
\text { - Sotatercept (ACE-011) in combination with } \\
\text { anti-MM therapy has bone anabolic effect [138] }\end{array}$ \\
\hline
\end{tabular}

Abbreviations: CCL, chemokine C-C motif ligand; MIP, macrophage inflammatory protein; DKK1, dickkopf-1; MM, multiple myeloma; OC, osteoclast; BMSCs, bone marrow stromal cells; OB, osteoblast; IL, interleukin; Th, T-helper lymphocytes; $\mathrm{mAb}$, monoclonal antibody; NF- $\mathrm{B}$, nuclear factor kappa B; VEGF, vascular endothelial growth factor; ZOL, zoledronate; MBD, myeloma bone disease.

\section{Concluding Remarks}

Despite therapeutic improvements, more than 40\% of MM patients suffer from SREs, and new treatment strategies are, therefore, needed. Skeletal disease and related complications are associated with significant morbidity and mortality rates in MM. In addition to bisphosphonates, which represented the standard of care for MBD during the last two decades, the RANKL inhibitor, denosumab, was approved in January 2018 for patients with active MM, providing a safe alternative to bisphosphonates in case of compromised renal function. Importantly, results of the MRC IX and "468" trials indicate that treatment with BMAs provides a survival advantage for patients with active 
MM [101,116]. The pathogenesis of bone disease in MM depends on OC activation, as well as on the inhibition of OBs and osteocytes. As a result, the balance of bone remodeling is irreversibly disrupted leading to defective bone repair. A major challenge in the treatment of MBD is to revert bone damage. Despite disease remission, conventional MM chemotherapies (i.e., melphalan and doxorubicin) are unable to completely heal lytic bone lesions [3]. However, recent studies suggest that proteasome inhibitors, in particular bortezomib, may promote bone repair via their anti-tumor and anabolic activities [4,5]. Bortezomib-induced bone sclerosis occurs in $20 \%$ to $72 \%$ of patients with osteolysis, depending on the line of treatment. Bone repair is independent from anti-MM response level and is heterogeneous, since only a small fraction of patients show signs of sclerosis in all lytic lesions. Based on these data, ongoing research revolves predominantly around agents which stimulate new bone formation, such as Pim2 kinase inhibitors which are currently being investigated in relapsed/refractory MM patients (NCT01456689) [154]. In addition, ongoing studies are evaluating the effect on bone turnover of novel anti-MM agents, including the proteasome inhibitor, ixazomib (NCT02499081), and the anti-CD38 antibody, daratumumab (NCT03475628). The ultimate goal is to restore a balanced bone remodeling, thereby not only improving MBD, but also reducing tumor burden, slowing down disease progression, and reverting bone damage.

Funding: This research received no external funding.

Conflicts of Interest: S.V. received travel support by Pfizer, Roche, Pierre Fabre, and Bristol Myers Squibb, and she acted as consultant for Roche Pharmaceuticals. K.P. received speaker honoraria from Celgene, Janssen, and Amgen. M.P. and K.P. received research support from Roche Pharmaceuticals. The companies had no role in the design of the study; in the collection, analyses, or interpretation of data; in the writing of the manuscript, and in the decision to publish the result.

\section{References}

1. Moreau, P.; San Miguel, J.; Sonneveld, P.; Mateos, M.V.; Zamagni, E.; Avet-Loiseau, H.; Hajek, R.; Dimopoulos, M.A.; Ludwig, H.; Einsele, H.; et al. Multiple myeloma: ESMO Clinical Practice Guidelines for diagnosis, treatment and follow-up. Ann. Oncol. 2017. [CrossRef] [PubMed]

2. Rajkumar, S.V.; Kumar, S. Multiple Myeloma: Diagnosis and Treatment. Mayo Clin. Proc. 2016. [CrossRef] [PubMed]

3. Rodriguez, L.; Finkelstein, J.; Shullenberger, C.C.; Alexanian, R. Bone healing in multiple myeloma with melphalan chemotherapy. Ann. Intern. Med. 1972, 76, 551-556. [CrossRef] [PubMed]

4. Schulze, M.; Weisel, K.; Grandjean, C.; Oehrlein, K.; Zago, M.; Spira, D.; Horger, M. Increasing bone sclerosis during bortezomib therapy in multiple myeloma patients: Results of a reduced-dose whole-body MDCT study. Am. J. Roentgenol. 2014. [CrossRef] [PubMed]

5. Hinge, M.; Andersen, K.T.; Lund, T.; Jørgensen, H.B.; Holdgaard, P.C.; Ormstrup, T.E.; Østergaard, L.L.; Plesner, T. Bone healing in multiple myeloma: A prospective evaluation of the impact of first-line anti-myeloma treatment. Haematologica 2016, 101, e419-e422. [CrossRef] [PubMed]

6. Silbermann, R.; Roodman, G.D. Myeloma bone disease: Pathophysiology and management. J. Bone Oncol. 2013, 2, 59-69. [CrossRef] [PubMed]

7. Zagouri, F.; Kastritis, E.; Zomas, A.; Terpos, E.; Katodritou, E.; Symeonidis, A.; Delimpasi, S.; Pouli, A.; Vassilakopoulos, T.P.; Michalis, E.; et al. Hypercalcemia remains an adverse prognostic factor for newly diagnosed multiple myeloma patients in the era of novel antimyeloma therapies. Eur. J. Haematol. 2017, 99, 409-414. [CrossRef] [PubMed]

8. Sonmez, M.; Akagun, T.; Topbas, M.; Cobanoglu, U.; Sonmez, B.; Yilmaz, M.; Ovali, E.; Omay, S.B. Effect of pathologic fractures on survival in multiple myeloma patients: A case control study. J. Exp. Clin. Cancer Res. 2008, 27. [CrossRef] [PubMed]

9. Roodman, G.D. Mechanisms of bone metastasis. N. Engl. J. Med. 2004, 350, 1655-1664. [CrossRef] [PubMed]

10. Terpos, E.; Ntanasis-Stathopoulos, I.; Gavriatopoulou, M.; Dimopoulos, M.A. Pathogenesis of bone disease in multiple myeloma: From bench to bedside. Blood Cancer J. 2018, 8, 7. [CrossRef] [PubMed] 
11. Pianko, M.J.; Terpos, E.; Roodman, G.D.; Divgi, C.R.; Zweegman, S.; Hillengass, J.; Lentzsch, S. Whole-body low-dose computed tomography and advanced imaging techniques for multiple myeloma bone disease. Clin. Cancer Res. 2014, 20, 5888-5897. [CrossRef] [PubMed]

12. Hillengass, J.; Moulopoulos, L.A.; Delorme, S.; Koutoulidis, V.; Mosebach, J.; Hielscher, T.; Drake, M.; Rajkumar, S.V.; Oestergaard, B.; Abildgaard, N.; et al. Whole-body computed tomography versus conventional skeletal survey in patients with multiple myeloma: A study of the International Myeloma Working Group. Blood Cancer J. 2017, 7, e599. [CrossRef] [PubMed]

13. Cavo, M.; Terpos, E.; Nanni, C.; Moreau, P.; Lentzsch, S.; Zweegman, S.; Hillengass, J.; Engelhardt, M.; Usmani, S.Z.; Vesole, D.H.; et al. Role of 18 F-FDG PET/CT in the diagnosis and management of multiple myeloma and other plasma cell disorders: A consensus statement by the International Myeloma Working Group. Lancet Oncol. 2017, 18, e206-e217. [CrossRef]

14. Raje, N.; Terpos, E.; Willenbacher, W.; Shimizu, K.; García-Sanz, R.; Durie, B.; Legieć, W.; Krejčí, M.; Laribi, K.; Zhu, L.; et al. Denosumab versus zoledronic acid in bone disease treatment of newly diagnosed multiple myeloma: An international, double-blind, double-dummy, randomised, controlled, phase 3 study. Lancet Oncol. 2018, 19, 370-381. [CrossRef]

15. Vallet, S.; Smith, M.R.; Raje, N. Novel bone-targeted strategies in oncology. Clin. Cancer Res. 2010, 16, 4084-4093. [CrossRef] [PubMed]

16. Buckwalter, J.A.; Glimcher, M.J.; Cooper, R.R.; Recker, R. Bone biology. Part I: Structure, blood supply, cells, matrix, and mineralization. J. Bone Jt. Surg. Ser. A 1995, 45, 371-386.

17. Raggatt, L.J.; Partridge, N.C. Cellular and molecular mechanisms of bone remodeling. J. Biol. Chem. 2010, 285, 25103-25108. [CrossRef] [PubMed]

18. Teitelbaum, S.L.; Ross, F.P. Genetic regulation of osteoclast development and function. Nat. Rev. Genet. 2003, 4, 638-649. [CrossRef] [PubMed]

19. Boyce, B.F.; Xing, L. Functions of RANKL/RANK/OPG in bone modeling and remodeling. Arch. Biochem. Biophys. 2008, 473, 139-146. [CrossRef] [PubMed]

20. Huang, W. Signaling and transcriptional regulation in osteoblast commitment and differentiation. Front. Biosci. 2007, 1, 3068-3092. [CrossRef]

21. Harada, S.; Rodan, G.A. Control of osteoblast function and regulation of bone mass. Nature 2003, 423, 349-355. [CrossRef] [PubMed]

22. Nakashima, T.; Hayashi, M.; Fukunaga, T.; Kurata, K.; Oh-Hora, M.; Feng, J.Q.; Bonewald, L.F.; Kodama, T.; Wutz, A.; Wagner, E.F.; et al. Evidence for osteocyte regulation of bone homeostasis through RANKL expression. Nat. Med. 2011, 17, 1231-1234. [CrossRef] [PubMed]

23. Winkler, D.G.; Sutherland, M.K.; Geoghegan, J.C.; Yu, C.; Hayes, T.; Skonier, J.E.; Shpektor, D.; Jonas, M.; Kovacevich, B.R.; Staehling-Hampton, K.; et al. Osteocyte control of bone formation via sclerostin, a novel BMP antagonist. EMBO J. 2003, 22, 6267-6276. [CrossRef] [PubMed]

24. Christenson, R.H. Biochemical markers of bone metabolism: An overview. Clin. Biochem. 1997, 30, $573-593$. [CrossRef]

25. Arnulf, B.; Lecourt, S.; Soulier, J.; Ternaux, B.; Lacassagne, M.N.; Crinquette, A.; Dessoly, J.; Sciaini, A.K.; Benbunan, M.; Chomienne, C.; et al. Phenotypic and functional characterization of bone marrow mesenchymal stem cells derived from patients with multiple myeloma. Leukemia 2007, 21, 158-163. [CrossRef] [PubMed]

26. Roccaro, A.M.; Sacco, A.; Maiso, P.; Azab, A.K.; Tai, Y.T.; Reagan, M.; Azab, F.; Flores, L.M.; Campigotto, F.; Weller, E.; et al. BM mesenchymal stromal cell-derived exosomes facilitate multiple myeloma progression. J. Clin. Investig. 2013, 123, 1542-1555. [CrossRef] [PubMed]

27. Wang, J.; Hendrix, A.; Hernot, S.; Lemaire, M.; De Bruyne, E.; Van Valckenborgh, E.; Lahoutte, T.; De Wever, O.; Vanderkerken, K.; Menu, E. Bone marrow stromal cell-derived exosomes as communicators in drug resistance in multiple myeloma cells. Blood 2014, 123, 1542-1555. [CrossRef] [PubMed]

28. Umezu, T.; Tadokoro, H.; Azuma, K.; Yoshizawa, S.; Ohyashiki, K.; Ohyashiki, J.H. Exosomal miR-135b shed from hypoxic multiple myeloma cells enhances angiogenesis by targeting factor-inhibiting HIF-1. Blood 2014, 124, 3748-3757. [CrossRef] [PubMed] 
29. Podar, K.; Zimmerhackl, A.; Fulciniti, M.; Tonon, G.; Hainz, U.; Tai, Y.-T.; Vallet, S.; Halama, N.; Jäger, D.; Olson, D.L.; et al. The selective adhesion molecule inhibitor Natalizumab decreases multiple myeloma cell growth in the bone marrow microenvironment: Therapeutic implications. Br. J. Haematol. 2011, 155, 438-448. [CrossRef] [PubMed]

30. Fan, F.; Bashari, M.H.; Morelli, E.; Tonon, G.; Malvestiti, S.; Vallet, S.; Jarahian, M.; Seckinger, A.; Hose, D.; Bakiri, L.; et al. The AP-1 transcription factor JunB is essential for multiple myeloma cell proliferation and drug resistance in the bone marrow microenvironment. Leukemia 2017, 31, 1570-1581. [CrossRef] [PubMed]

31. Abe, M.; Hiura, K.; Wilde, J.; Shioyasono, A.; Moriyama, K.; Hashimoto, T.; Kido, S.; Oshima, T.; Shibata, H.; Ozaki, S.; et al. Osteoclasts enhance myeloma cell growth and survival via cell-cell contact: A vicious cycle between bone destruction and myeloma expansion. Blood 2004, 104, 2484-2491. [CrossRef] [PubMed]

32. Li, X.; Pennisi, A.; Yaccoby, S. Role of decorin in the antimyeloma effects of osteoblasts. Blood 2008, 112, 159-168. [CrossRef] [PubMed]

33. Yaccoby, S.; Wezeman, M.J.; Zangari, M.; Walker, R.; Cottler-Fox, M.; Gaddy, D.; Ling, W.; Saha, R.; Barlogie, B.; Tricot, G.; et al. Inhibitory effects of osteoblasts and increased bone formation on myeloma in novel culture systems and a myelomatous mouse model. Haematologica 2006, 91, 192-199. [PubMed]

34. Lawson, M.A.; McDonald, M.M.; Kovacic, N.; Khoo, W.H.; Terry, R.L.; Down, J.; Kaplan, W.; Paton-Hough, J.; Fellows, C.; Pettitt, J.A.; et al. Osteoclasts control reactivation of dormant myeloma cells by remodelling the endosteal niche. Nat. Commun. 2015, 6, 8993. [CrossRef] [PubMed]

35. Delgado-Calle, J.; Anderson, J.; Cregor, M.D.; Hiasa, M.; Chirgwin, J.M.; Carlesso, N.; Yoneda, T.; Mohammad, K.S.; Plotkin, L.I.; Roodman, G.D.; et al. Bidirectional notch signaling and osteocyte-derived factors in the bone marrow microenvironment promote tumor cell proliferation and bone destruction in multiple myeloma. Cancer Res. 2016, 76, 1089-1100. [CrossRef] [PubMed]

36. Trotter, T.N.; Gibson, J.T.; Sherpa, T.L.; Gowda, P.S.; Peker, D.; Yang, Y. Adipocyte-Lineage Cells Support Growth and Dissemination of Multiple Myeloma in Bone. Am. J. Pathol. 2016, 186, 3054-3063. [CrossRef] [PubMed]

37. Caers, J.; Deleu, S.; Belaid, Z.; De Raeve, H.; Van Valckenborgh, E.; De Bruyne, E.; DeFresne, M.P.; Van Riet, I.; Van Camp, B.; Vanderkerken, K. Neighboring adipocytes participate in the bone marrow microenvironment of multiple myeloma cells. Leukemia 2007, 21, 1580-1584. [CrossRef] [PubMed]

38. Bullwinkle, E.M.; Parker, M.D.; Bonan, N.F.; Falkenberg, L.G.; Davison, S.P.; DeCicco-Skinner, K.L. Adipocytes contribute to the growth and progression of multiple myeloma: Unraveling obesity related differences in adipocyte signaling. Cancer Lett. 2016, 380, 114-121. [CrossRef] [PubMed]

39. Pang, J.; Shi, Q.; Liu, Z.; He, J.; Liu, H.; Lin, P.; Cui, J.; Yang, J. Resistin induces multidrug resistance in myeloma by inhibiting cell death and upregulating ABC transporter expression. Haematologica 2017, 102, 1273-1280. [CrossRef] [PubMed]

40. Pratt, G.; Goodyear, O.; Moss, P. Immunodeficiency and immunotherapy in multiple myeloma. Br. J. Haematol. 2007, 138, 563-579. [CrossRef] [PubMed]

41. Favreau, M.; Menu, E.; Gaublomme, D.; Vanderkerken, K.; Faict, S.; Maes, K.; De Bruyne, E.; Govindarajan, S.; Drennan, M.; Van Calenbergh, S.; et al. Leptin receptor antagonism of iNKT cell function: A novel strategy to combat multiple myeloma. Leukemia 2017, 31, 2678-2685. [CrossRef] [PubMed]

42. Prabhala, R.H.; Pelluru, D.; Fulciniti, M.; Prabhala, H.K.; Nanjappa, P.; Song, W.; Pai, C.; Amin, S.; Tai, Y.T.; Richardson, P.G.; et al. Elevated IL-17 produced by TH17 cells promotes myeloma cell growth and inhibits immune function in multiple myeloma. Blood 2010, 115, 5385-5392. [CrossRef] [PubMed]

43. El-Sherbiny, Y.M.; Meade, J.L.; Holmes, T.D.; McGonagle, D.; Mackie, S.L.; Morgan, A.W.; Cook, G.; Feyler, S.; Richards, S.J.; Davies, F.E.; et al. The requirement for DNAM-1, NKG2D, and NKp46 in the natural killer cell-mediated killing of myeloma cells. Cancer Res. 2007, 67, 8444-8449. [CrossRef] [PubMed]

44. Benson, D.M.; Bakan, C.E.; Mishra, A.; Hofmeister, C.C.; Efebera, Y.; Becknell, B.; Baiocchi, R.A.; Zhang, J.; Yu, J.; Smith, M.K.; et al. The PD-1/PD-L1 axis modulates the natural killer cell versus multiple myeloma effect: A therapeutic target for CT-011, a novel monoclonal anti-PD-1 antibody. Blood 2010, 116, 2286-2294. [CrossRef] [PubMed]

45. Costello, R.T.; Boehrer, A.; Sanchez, C.; Mercier, D.; Baier, C.; Le Treut, T.; Sébahoun, G. Differential expression of natural killer cell activating receptors in blood versus bone marrow in patients with monoclonal gammopathy. Immunology 2013, 139, 338-341. [CrossRef] [PubMed] 
46. Chauhan, D.; Singh, A.V.; Brahmandam, M.; Carrasco, R.; Bandi, M.; Hideshima, T.; Bianchi, G.; Podar, K.; Tai, Y.T.; Mitsiades, C.; et al. Functional interaction of plasmacytoid dendritic cells with multiple myeloma cells: A therapeutic target. Cancer Cell 2009, 16, 309-323. [CrossRef] [PubMed]

47. Tai, Y.; Cho, S.; Anderson, K. Osteoclast Immunosuppressive Effects in Multiple Myeloma: Role of Programmed Cell Death Ligand 1. Front. Immunol. 2018, 10, 1822. [CrossRef] [PubMed]

48. Melton, L.J., 3rd; Rajkumar, S.V.; Khosla, S.; Achenbach, S.J.; Oberg, A.L.; Kyle, R.A. Fracture risk in monoclonal gammopathy of undetermined significance. J. Bone Miner. Res. 2004, 19, 25-30. [CrossRef] [PubMed]

49. Bataille, R.; Chappard, D.; Marcelli, C.; Dessauw, P.; Sany, J.; Baldet, P.; Alexandre, C. Mechanisms of bone destruction in multiple myeloma: The importance of an unbalanced process in determining the severity of lytic bone disease. J. Clin. Oncol. 1989, 7, 1909-1914. [CrossRef] [PubMed]

50. Bataille, R.; Chappard, D.; Basle, M.F. Quantifiable excess of bone resorption in monoclonal gammopathy is an early symptom of malignancy: A prospective study of 87 bone biopsies. Blood 1996, 87, 4762-4769. [PubMed]

51. Vallet, S.; Hoyle, N.R.; Kyle, R.A.; Podar, K.; Pecherstorfer, M. A role for bone turnover markers $\beta$-CrossLaps (CTX) and amino-terminal propeptide of type I collagen (PINP) as potential indicators for disease progression from MGUS to multiple myeloma. Leuk. Lymphoma 2018, 18, 1-8. [CrossRef] [PubMed]

52. Terpos, E.; Dimopoulos, M.A.; Sezer, O.; Roodman, D.; Abildgaard, N.; Vescio, R.; Tosi, P.; Garcia-Sanz, R.; Davies, F.; Chanan-Khan, A.; et al. The use of biochemical markers of bone remodeling in multiple myeloma: A report of the International Myeloma Working Group. Leukemia 2010, 24, 1700-1712. [CrossRef] [PubMed]

53. Raimondi, L.; De Luca, A.; Amodio, N.; Manno, M.; Raccosta, S.; Taverna, S.; Bellavia, D.; Naselli, F.; Fontana, S.; Schillaci, O.; et al. Involvement of multiple myeloma cell-derived exosomes in osteoclast differentiation. Oncotarget 2015, 6, 13772-13789. [CrossRef] [PubMed]

54. Giuliani, N.; Ferretti, M.; Bolzoni, M.; Storti, P.; Lazzaretti, M.; Dalla Palma, B.; Bonomini, S.; Martella, E.; Agnelli, L.; Neri, A.; et al. Increased osteocyte death in multiple myeloma patients: Role in myeloma-induced osteoclast formation. Leukemia 2012, 26, 1391-1401. [CrossRef] [PubMed]

55. Kong, Y.Y.; Yoshida, H.; Sarosi, I.; Tan, H.L.; Timms, E.; Capparelli, C.; Morony, S.; Oliveira-dos-Santos, A.J.; Van, G.; Itie, A.; et al. OPGL is a key regulator of osteoclastogenesis, lymphocyte development and lymph-node organogenesis. Nature 1999, 397, 315-323. [CrossRef] [PubMed]

56. Giuliani, N.; Colla, S.; Sala, R.; Moroni, M.; Lazzaretti, M.; La Monica, S.; Bonomini, S.; Hojden, M.; Sammarelli, G.; Barille, S.; et al. Human myeloma cells stimulate the receptor activator of nuclear factor-kappa B ligand (RANKL) in T lymphocytes: A potential role in multiple myeloma bone disease. Blood 2002, 100, 4615-4621. [CrossRef] [PubMed]

57. Sezer, O.; Heider, U.; Zavrski, I.; Kuhne, C.A.; Hofbauer, L.C. RANK ligand and osteoprotegerin in myeloma bone disease. Blood 2003, 101, 2094-2098. [CrossRef] [PubMed]

58. Kopan, R.; Ilagan, M.X.G. The Canonical Notch Signaling Pathway: Unfolding the Activation Mechanism. Cell 2009, 137, 216-233. [CrossRef] [PubMed]

59. Previs, R.A.; Coleman, R.L.; Harris, A.L.; Sood, A.K. Molecular pathways: Translational and therapeutic implications of the Notch signaling pathway in cancer. Clin. Cancer Res. 2015, 21, 955-961. [CrossRef] [PubMed]

60. Colombo, M.; Mirandola, L.; Platonova, N.; Apicella, L.; Basile, A.; Figueroa, A.J.; Cobos, E.; Chiriva-Internati, M.; Chiaramonte, R. Notch-directed microenvironment reprogramming in myeloma: A single path to multiple outcomes. Leukemia 2013, 27, 1009-1018. [CrossRef] [PubMed]

61. Colombo, M.; Thümmler, K.; Mirandola, L.; Garavelli, S.; Todoerti, K.; Apicella, L.; Lazzari, E.; Lancellotti, M.; Platonova, N.; Akbar, M.; et al. Notch signaling drives multiple myeloma induced osteoclastogenesis. Oncotarget 2014, 5, 10393-10406. [CrossRef] [PubMed]

62. Vallet, S.; Raje, N.; Ishitsuka, K.; Hideshima, T.; Podar, K.; Chhetri, S.; Pozzi, S.; Breitkreutz, I.; Kiziltepe, T.; Yasui, H.; et al. MLN3897, a novel CCR1 inhibitor, impairs osteoclastogenesis and inhibits the interaction of multiple myeloma cells and osteoclasts. Blood 2007, 110, 3744-3752. [CrossRef] [PubMed]

63. Matsumoto, T.; Abe, M. Bone destruction in multiple myeloma. Ann. N. Y. Acad. Sci. 2006, 1068, 319-326. [CrossRef] [PubMed] 
64. Tsubaki, M.; Kato, C.; Manno, M.; Ogaki, M.; Satou, T.; Itoh, T.; Kusunoki, T.; Tanimori, Y.; Fujiwara, K.; Matsuoka, H.; et al. Macrophage inflammatory protein-1alpha (MIP-1alpha) enhances a receptor activator of nuclear factor kappaB ligand (RANKL) expression in mouse bone marrow stromal cells and osteoblasts through MAPK and PI3K/Akt pathways. Mol. Cell. Biochem. 2007, 304, 53-60. [CrossRef] [PubMed]

65. Terpos, E.; Politou, M.; Szydlo, R.; Goldman, J.M.; Apperley, J.F.; Rahemtulla, A. Serum levels of macrophage inflammatory protein-1 alpha (MIP-1alpha) correlate with the extent of bone disease and survival in patients with multiple myeloma. Br. J. Haematol. 2003, 123, 106-109. [CrossRef] [PubMed]

66. Giuliani, N.; Lisignoli, G.; Colla, S.; Lazzaretti, M.; Storti, P.; Mancini, C.; Bonomini, S.; Manferdini, C.; Codeluppi, K.; Facchini, A.; et al. CC-Chemokine ligand 20/macrophage inflammatory protein-3alpha and CC-chemokine receptor 6 are overexpressed in myeloma microenvironment related to osteolytic bone lesions. Cancer Res. 2008, 68, 6840-6850. [CrossRef] [PubMed]

67. Dalla Palma, B.; Guasco, D.; Pedrazzoni, M.; Bolzoni, M.; Accardi, F.; Costa, F.; Sammarelli, G.; Craviotto, L.; De Filippo, M.; Ruffini, L.; et al. Osteolytic lesions, cytogenetic features and bone marrow levels of cytokines and chemokines in multiple myeloma patients: Role of chemokine (C-C motif) ligand 20. Leukemia 2016, 30, 409-416. [CrossRef] [PubMed]

68. Hideshima, T.; Chauhan, D.; Schlossman, R.; Richardson, P.; Anderson, K.C. The role of tumor necrosis factor $\alpha$ in the pathophysiology of human multiple myeloma: Therapeutic applications. Oncogene 2001, 20, 4519-4527. [CrossRef] [PubMed]

69. Lam, J.; Takeshita, S.; Barker, J.E.; Kanagawa, O.; Ross, F.P.; Teitelbaum, S.L. TNF- $\alpha$ induces osteoclastogenesis by direct stimulation of macrophages exposed to permissive levels of RANK ligand. J. Clin. Investig. 2000, 106, 1481-1488. [CrossRef] [PubMed]

70. Lu, X.; Gilbert, L.; He, X.; Rubin, J.; Nanes, M.S. Transcriptional regulation of the osterix (Osx, Sp7) promoter by tumor necrosis factor identifies disparate effects of mitogen-activated protein kinase and NF kappa B pathways. J. Biol. Chem. 2006, 281, 6297-6306. [CrossRef] [PubMed]

71. Udagawa, N.; Takahashi, N.; Katagiri, T.; Tamura, T.; Wada, S.; Findlay, D.M.; Martin, T.J.; Hirota, H.; Taga, T.; Kishimoto, T; et al. Interleukin (IL)-6 induction of osteoclast differentiation depends on IL-6 receptors expressed on osteoblastic cells but not on osteoclast progenitors. J. Exp. Med. 1995, 182, 1461-1468. [CrossRef] [PubMed]

72. Lee, J.W.; Chung, H.Y.; Ehrlich, L.A.; Jelinek, D.F.; Callander, N.S.; Roodman, G.D.; Choi, S.J. IL-3 expression by myeloma cells increases both osteoclast formation and growth of myeloma cells. Blood 2004, 103, 2308-2315. [CrossRef] [PubMed]

73. Ehrlich, L.A.; Chung, H.Y.; Ghobrial, I.; Choi, S.J.; Morandi, F.; Colla, S.; Rizzoli, V.; Roodman, G.D.; Giuliani, N. IL-3 is a potential inhibitor of osteoblast differentiation in multiple myeloma. Blood 2005, 106, 1407-1414. [CrossRef] [PubMed]

74. Silbermann, R.; Bolzoni, M.; Storti, P.; Guasco, D.; Bonomini, S.; Zhou, D.; Wu, J.; Anderson, J.L.; Windle, J.J.; Aversa, F.; et al. Bone marrow monocyte-/macrophage-derived activin A mediates the osteoclastogenic effect of IL-3 in multiple myeloma. Leukemia 2014, 28, 951-954. [CrossRef] [PubMed]

75. Noonan, K.; Marchionni, L.; Anderson, J.; Pardoll, D.; Roodman, G.D.; Borrello, I. A novel role of IL-17-producing lymphocytes in mediating lytic bone disease in multiple myeloma. Blood 2010, 116, 3554-3563. [CrossRef] [PubMed]

76. Kawano, M.; Yamamoto, I.; Iwato, K.; Tanaka, H.; Asaoku, H.; Tanabe, O.; Ishikawa, H.; Nobuyoshi, M.; Ohmoto, Y.; Hirai, Y.; et al. Interleukin-1 beta rather than lymphotoxin as the major bone resorbing activity in human multiple myeloma. Blood 1989, 73, 1646-1649. [PubMed]

77. Hjertner, O.; Torgersen, M.L.; Seidel, C.; Hjorth-Hansen, H.; Waage, A.; Børset, M.; Sundan, A. Hepatocyte growth factor (HGF) induces interleukin-11 secretion from osteoblasts: A possible role for HGF in myeloma-associated osteolytic bone disease. Blood 1999, 94, 3883-3888. [PubMed]

78. Bennett, C.N.; Longo, K.A.; Wright, W.S.; Suva, L.J.; Lane, T.F.; Hankenson, K.D.; MacDougald, O.A. Regulation of osteoblastogenesis and bone mass by Wnt10b. Proc. Natl. Acad. Sci. USA 2005, 102, 3324-3329. [CrossRef] [PubMed]

79. Boyden, L.M.; Mao, J.; Belsky, J.; Mitzner, L.; Farhi, A.; Mitnick, M.A.; Wu, D.; Insogna, K.; Lifton, R.P. High Bone Density Due to a Mutation in LDL-Receptor-Related Protein 5. N. Engl. J. Med. 2002, 346, 1513-1521. [CrossRef] [PubMed] 
80. Baron, R.; Kneissel, M. WNT signaling in bone homeostasis and disease: From human mutations to treatments. Nat. Med. 2013, 19, 179-192. [CrossRef] [PubMed]

81. Spaan, I.; Raymakers, R.A.; Van De Stolpe, A.; Peperzak, V. Wnt signaling in multiple myeloma: A central player in disease with therapeutic potential. J. Hematol. Oncol. 2018, 11, 67. [CrossRef] [PubMed]

82. Politou, M.C.; Heath, D.J.; Rahemtulla, A.; Szydlo, R.; Anagnostopoulos, A.; Dimopoulos, M.A.; Croucher, P.I.; Terpos, E. Serum concentrations of Dickkopf-1 protein are increased in patients with multiple myeloma and reduced after autologous stem cell transplantation. Int. J. Cancer 2006, 119, 1728-1731. [CrossRef] [PubMed]

83. Eda, H.; Santo, L.; Wein, M.N.; Hu, D.Z.; Cirstea, D.D.; Nemani, N.; Tai, Y.T.; Raines, S.E.; Kuhstoss, S.A.; Munshi, N.C.; et al. Regulation of Sclerostin Expression in Multiple Myeloma by Dkk-1: A Potential Therapeutic Strategy for Myeloma Bone Disease. J. Bone Miner. Res. 2016, 31, 1225-1234. [CrossRef] [PubMed]

84. Leupin, O.; Piters, E.; Halleux, C.; Hu, S.; Kramer, I.; Morvan, F.; Bouwmeester, T.; Schirle, M.; Bueno-Lozano, M.; Ramos Fuentes, F.J.; et al. Bone overgrowth-associated mutations in the LRP4 gene impair sclerostin facilitator function. J. Biol. Chem. 2011, 286, 19489-19500. [CrossRef] [PubMed]

85. Delgado-Calle, J.; Sato, A.Y.; Bellido, T. Role and mechanism of action of sclerostin in bone. Bone 2017, 96, 29-37. [CrossRef] [PubMed]

86. Kamiya, N.; Ye, L.; Kobayashi, T.; Mochida, Y.; Yamauchi, M.; Kronenberg, H.M.; Feng, J.Q.; Mishina, Y. BMP signaling negatively regulates bone mass through sclerostin by inhibiting the canonical Wnt pathway. Development 2008, 135, 3801-3811. [CrossRef] [PubMed]

87. Delgado-Calle, J.; Anderson, J.; Cregor, M.D.; Condon, K.W.; Kuhstoss, S.A.; Plotkin, L.I.; Bellido, T.; Roodman, G.D. Genetic deletion of Sost or pharmacological inhibition of sclerostin prevent multiple myeloma-induced bone disease without affecting tumor growth. Leukemia 2017, 31, 2686-2694. [CrossRef] [PubMed]

88. Tian, E.; Zhan, F.; Walker, R.; Rasmussen, E.; Ma, Y.; Barlogie, B.; Shaughnessy, J.D., Jr. The role of the Wnt-signaling antagonist DKK1 in the development of osteolytic lesions in multiple myeloma. N. Engl. J. Med. 2003, 349, 2483-2494. [CrossRef] [PubMed]

89. Gunn, W.G.; Conley, A.; Deininger, L.; Olson, S.D.; Prockop, D.J.; Gregory, C.A. A crosstalk between myeloma cells and marrow stromal cells stimulates production of DKK1 and interleukin-6: A potential role in the development of lytic bone disease and tumor progression in multiple myeloma. Stem Cells 2006, 24, 986-991. [CrossRef] [PubMed]

90. Wu, P.; Walker, B.A.; Brewer, D.; Gregory, W.M.; Ashcroft, J.; Ross, F.M.; Jackson, G.H.; Child, A.J.; Davies, F.E.; Morgan, G.J. A gene expression-based predictor for myeloma patients at high risk of developing bone disease on bisphosphonate treatment. Clin. Cancer Res. 2011, 17, 6347-6355. [CrossRef] [PubMed]

91. Bolzoni, M.; Donofrio, G.; Storti, P.; Guasco, D.; Toscani, D.; Lazzaretti, M.; Bonomini, S.; Agnelli, L.; Capocefalo, A.; Dalla Palma, B.; et al. Myeloma cells inhibit non-canonical wnt co-receptor ror2 expression in human bone marrow osteoprogenitor cells: Effect of wnt5a/ror2 pathway activation on the osteogenic differentiation impairment induced by myeloma cells. Leukemia 2013, 27, 451-463. [CrossRef] [PubMed]

92. Vallet, S.; Mukherjee, S.; Vaghela, N.; Hideshima, T.; Fulciniti, M.; Pozzi, S.; Santo, L.; Cirstea, D.; Patel, K.; Sohani, A.R.; et al. Activin A promotes multiple myeloma-induced osteolysis and is a promising target for myeloma bone disease. Proc. Natl. Acad. Sci. USA 2010, 107, 5124-5129. [CrossRef] [PubMed]

93. Fuller, K.; Bayley, K.E.; Chambers, T.J. Activin A is an essential cofactor for osteoclast induction. Biochem. Biophys. Res. Commun. 2000, 268, 2-7. [CrossRef] [PubMed]

94. Giuliani, N.; Colla, S.; Morandi, F.; Lazzaretti, M.; Sala, R.; Bonomini, S.; Grano, M.; Colucci, S.; Svaldi, M.; Rizzoli, V. Myeloma cells block RUNX2/CBFA1 activity in human bone marrow osteoblast progenitors and inhibit osteoblast formation and differentiation. Blood 2005, 106, 2472-2483. [CrossRef] [PubMed]

95. Vallet, S.; Pozzi, S.; Patel, K.; Vaghela, N.; Fulciniti, M.T.; Veiby, P.; Hideshima, T.; Santo, L.; Cirstea, D.; Scadden, D.T.; et al. A novel role for CCL3 (MIP-1 $\alpha)$ in myeloma-induced bone disease via osteocalcin downregulation and inhibition of osteoblast function. Leukemia 2011, 25, 1174-1181. [CrossRef] [PubMed]

96. Kassen, D.; Lath, D.; Lach, A.; Evans, H.; Chantry, A.; Rabin, N.; Croucher, P.; Yong, K.L. Myeloma impairs mature osteoblast function but causes early expansion of osteo-progenitors: Temporal changes in bone physiology and gene expression in the KMS12BM model. Br. J. Haematol. 2016, 172, 64-79. [CrossRef] [PubMed] 
97. Anderson, K.; Ismaila, N.; Flynn, P.J.; Halabi, S.; Jagannath, S.; Ogaily, M.S.; Omel, J.; Raje, N.; Roodman, G.D.; Yee, G.C.; et al. Role of bone-modifying agents in multiple myeloma: American society of clinical oncology clinical practice guideline update. J. Clin. Oncol. 2018, 36, 812-818. [CrossRef] [PubMed]

98. Vallet, S.; Podar, K. New insights, recent advances, and current challenges in the biological treatment of multiple myeloma. Expert Opin. Biol. Ther. 2013, 13, S35-S53. [CrossRef] [PubMed]

99. Raje, N.; Anderson, K.C. Introduction: The evolving role of bisphosphonate therapy in multiple myeloma. Blood 2000, 96, 381-383. [PubMed]

100. Dunford, J.E.; Kwaasi, A.A.; Rogers, M.J.; Barnett, B.L.; Ebetino, F.H.; Russell, R.G.; Oppermann, U.; Kavanagh, K.L. Structure-activity relationships among the nitrogen containing bisphosphonates in clinical use and other analogues: Time-dependent inhibition of human farnesyl pyrophosphate synthase. J. Med. Chem. 2008, 51, 2187-2195. [CrossRef] [PubMed]

101. Morgan, G.J.; Davies, F.E.; Gregory, W.M.; Cocks, K.; Bell, S.E.; Szubert, A.J.; Navarro-Coy, N.; Drayson, M.T.; Owen, R.G.; Feyler, S.; et al. First-line treatment with zoledronic acid as compared with clodronic acid in multiple myeloma (MRC Myeloma IX): A randomised controlled trial. Lancet 2010, 376, 1989-1999. [CrossRef]

102. Perazella, M.A.; Markowitz, G.S. Bisphosphonate nephrotoxicity. Kidney Int. 2008, 74, 1385-1393. [CrossRef] [PubMed]

103. Kyle, R.A.; Yee, G.C.; Somerfield, M.R.; Flynn, P.J.; Halabi, S.; Jagannath, S.; Orlowski, R.Z.; Roodman, D.G.; Twilde, P.; Anderson, K. American Society of Clinical Oncology 2007 clinical practice guideline update on the role of bisphosphonates in multiple myeloma. J. Clin. Oncol. 2007, 25, 2464-2472. [CrossRef] [PubMed]

104. Raje, N.; Woo, S.-B.; Hande, K.; Yap, J.T.; Richardson, P.G.; Vallet, S.; Treister, N.; Hideshima, T.; Sheehy, N.; Chhetri, S.; et al. Clinical, radiographic, and biochemical characterization of multiple myeloma patients with osteonecrosis of the jaw. Clin. Cancer Res. 2008, 14, 2387-2395. [CrossRef] [PubMed]

105. Schilcher, J.; Aspenberg, P. Incidence of stress fractures of the femoral shaft in women treated with bisphosphonate. Acta Orthop. 2009, 80, 413-415. [CrossRef] [PubMed]

106. Black, D.M.; Kelly, M.P.; Genant, H.K.; Palermo, L.; Eastell, R.; Bucci-Rechtweg, C.; Cauley, J.; Leung, P.C.; Boonen, S.; Santora, A.; et al. Bisphosphonates and Fractures of the Subtrochanteric or Diaphyseal Femur. N. Engl. J. Med. 2010, 362, 1761-1771. [CrossRef] [PubMed]

107. Allen, M.R. Bisphosphonate effects on bone turnover, microdamage, and mechanical properties: What we think we know and what we know that we don't know. Bone 2011, 49, 56-65. [CrossRef] [PubMed]

108. Van der Meulen, M.C.H.; Boskey, A.L. Atypical subtrochanteric femoral shaft fractures: Role for mechanics and bone quality. Arthritis Res. Ther. 2012, 14, 220. [CrossRef] [PubMed]

109. Raje, N.; Vescio, R.; Montgomery, C.W.; Badros, A.; Munshi, N.; Orlowski, R.; Hadala, J.T.; Warsi, G.; Argonza-Aviles, E.; Ericson, S.G.; et al. Bone marker-directed dosing of zoledronic acid for the prevention of skeletal complications in patients with multiple myeloma: Results of the Z-MARK study. Clin. Cancer Res. 2016, 22, 1378-1384. [CrossRef] [PubMed]

110. Kostenuik, P.J.; Nguyen, H.Q.; McCabe, J.; Warmington, K.S.; Kurahara, C.; Sun, N.; Chen, C.; Li, L.; Cattley, R.C.; Van, G.; et al. Denosumab, a fully human monoclonal antibody to RANKL, inhibits bone resorption and increases BMD in knock-in mice that express chimeric (murine/human) RANKL. J. Bone Miner. Res. 2009, 24, 182-195. [CrossRef] [PubMed]

111. McClung, M.R.; Lewiecki, E.M.; Cohen, S.B.; Bolognese, M.A.; Woodson, G.C.; Moffett, A.H.; Peacock, M.; Miller, P.D.; Lederman, S.N.; Chesnut, C.H.; et al. Denosumab in postmenopausal women with low bone mineral density. N. Engl. J. Med. 2006, 354, 821-831. [CrossRef] [PubMed]

112. Lipton, A.; Steger, G.G.; Figueroa, J.; Alvarado, C.; Solal-Celigny, P.; Body, J.J.; de Boer, R.; Berardi, R.; Gascon, P.; Tonkin, K.S.; et al. Randomized active-controlled phase II study of denosumab efficacy and safety in patients with breast cancer-related bone metastases. J. Clin. Oncol. 2007, 25, 4431-4437. [CrossRef] [PubMed]

113. Vij, R.; Horvath, N.; Spencer, A.; Taylor, K.; Vadhan-Raj, S.; Vescio, R.; Smith, J.; Qian, Y.; Yeh, H.; Jun, S. An open-label, phase 2 trial of denosumab in the treatment of relapsed or plateau-phase multiple myeloma. Am. J. Hematol. 2009, 84, 650-656. [CrossRef] [PubMed] 
114. Henry, D.H.; Costa, L.; Goldwasser, F.; Hirsh, V.; Hungria, V.; Prausova, J.; Scagliotti, G.V.; Sleeboom, H.; Spencer, A.; Vadhan-Raj, S.; et al. Randomized, double-blind study of denosumab versus zoledronic acid in the treatment of bone metastases in patients with advanced cancer (excluding breast and prostate cancer) or multiple myeloma. J. Clin. Oncol. 2011, 29, 1125-1132. [CrossRef] [PubMed]

115. Raje, N.; Vadhan-Raj, S.; Willenbacher, W.; Terpos, E.; Hungria, V.; Spencer, A.; Alexeeva, Y.; Facon, T.; Stewart, A.K.; Feng, A.; et al. Evaluating results from the multiple myeloma patient subset treated with denosumab or zoledronic acid in a randomized phase 3 trial. Blood Cancer J. 2016, 6, e378. [CrossRef] [PubMed]

116. Terpos, E.; Roodman, D.; Willenbacher, W.; Shimizu, K.; García-Sanz, R.; Durie, B.; Zhu, L.; Bhatta, S.; Raje, N. Comparison of denosumab with zoledronic acid for the treatment of bone disease in patients with newly diagnosed Multiple Myeloma; an international, randomized, double blind trial. EHA 2017, 102, S782.

117. Roccaro, A.M.; Hideshima, T.; Richardson, P.G.; Russo, D.; Ribatti, D.; Vacca, A.; Dammacco, F.; Anderson, K.C. Bortezomib as an antitumor agent. Curr. Pharm. Biotechnol. 2006, 7, 441-448. [CrossRef] [PubMed]

118. Mukherjee, S.; Raje, N.; Schoonmaker, J.A.; Liu, J.C.; Hideshima, T.; Wein, M.N.; Jones, D.C.; Vallet, S.; Bouxsein, M.L.; Pozzi, S.; et al. Pharmacologic targeting of a stem/progenitor population in vivo is associated with enhanced bone regeneration in mice. J. Clin. Investig. 2008, 118, 491-504. [CrossRef] [PubMed]

119. Von Metzler, I.; Krebbel, H.; Hecht, M.; Manz, R.A.; Fleissner, C.; Mieth, M.; Kaiser, M.; Jakob, C.; Sterz, J.; Kleeberg, L.; et al. Bortezomib inhibits human osteoclastogenesis. Leukemia 2007, 21, 2025-2034. [CrossRef] [PubMed]

120. Zangari, M.; Esseltine, D.; Lee, C.K.; Barlogie, B.; Elice, F.; Burns, M.J.; Kang, S.H.; Yaccoby, S.; Najarian, K.; Richardson, P.; et al. Response to bortezomib is associated to osteoblastic activation in patients with multiple myeloma. Br. J. Haematol. 2005, 131, 71-73. [CrossRef] [PubMed]

121. Giuliani, N.; Morandi, F.; Tagliaferri, S.; Lazzaretti, M.; Bonomini, S.; Crugnola, M.; Mancini, C.; Martella, E.; Ferrari, L.; Tabilio, A.; et al. The proteasome inhibitor bortezomib affects osteoblast differentiation in vitro and in vivo in multiple myeloma patients. Blood 2007, 110, 334-338. [CrossRef] [PubMed]

122. Lund, T.; Søe, K.; Abildgaard, N.; Garnero, P.; Pedersen, P.T.; Ormstrup, T.; Delaissé, J.M.; Plesner, T. First-line treatment with bortezomib rapidly stimulates both osteoblast activity and bone matrix deposition in patients with multiple myeloma, and stimulates osteoblast proliferation and differentiation in vitro. Eur. J. Haematol. 2010, 85, 290-299. [CrossRef] [PubMed]

123. Toscani, D.; Palumbo, C.; Dalla Palma, B.; Ferretti, M.; Bolzoni, M.; Marchica, V.; Sena, P.; Martella, E.; Mancini, C.; Ferri, V.; et al. The Proteasome Inhibitor Bortezomib Maintains Osteocyte Viability in Multiple Myeloma Patients by Reducing both Apoptosis and Autophagy: A New Function for Proteasome Inhibitors. J. Bone Miner. Res. 2016, 31, 815-827. [CrossRef] [PubMed]

124. Anderson, G.; Gries, M.; Kurihara, N.; Honjo, T.; Anderson, J.; Donnenberg, V.; Donnenberg, A.; Ghobrial, I.; Mapara, M.Y.; Stirling, D.; et al. Thalidomide derivative CC-4047 inhibits osteoclast formation by down-regulation of PU.1. Blood 2006, 107, 3098-3105. [CrossRef] [PubMed]

125. Breitkreutz, I.; Raab, M.S.; Vallet, S.; Hideshima, T.; Raje, N.; Mitsiades, C.; Chauhan, D.; Okawa, Y.; Munshi, N.C.; Richardson, P.G.; et al. Lenalidomide inhibits osteoclastogenesis, survival factors and bone-remodeling markers in multiple myeloma. Leukemia 2008, 22, 1925-1932. [CrossRef] [PubMed]

126. Bolzoni, M.; Storti, P.; Bonomini, S.; Todoerti, K.; Guasco, D.; Toscani, D.; Agnelli, L.; Neri, A.; Rizzoli, V.; Giuliani, N. Immunomodulatory drugs lenalidomide and pomalidomide inhibit multiple myeloma-induced osteoclast formation and the RANKL/OPG ratio in the myeloma microenvironment targeting the expression of adhesion molecules. Exp. Hematol. 2012, 41, 387-397. [CrossRef] [PubMed]

127. Terpos, E.; Christoulas, D.; Gkotzamanidou, M.; Bratengeier, C.; Gavriatopoulou, M.; Migkou, M.; Papatheodorou, A.; Kastritis, E.; Woloszczuk, W.; Dimopoulos, M.A.C.E.T. Circulating Levels of the Wnt Inhibitors Dickkopf-1 and Sclerostin in Different Phases of Multiple Myeloma: Alterations Post-Therapy with Lenalidomide and Dexamethasone with or without Bortezomib. Blood 2010, 116, 2963.

128. Fulciniti, M.; Tassone, P.; Hideshima, T.; Vallet, S.; Nanjappa, P.; Ettenberg, S.A.; Shen, Z.; Patel, N.; Tai, Y.-T.; Chauhan, D.; et al. Anti-DKK1 mAb (BHQ880) as a potential therapeutic agent for multiple myeloma. Blood 2009, 114, 371-379. [CrossRef] [PubMed] 
129. Qian, J.; Zheng, Y.; Zheng, C.; Wang, L.; Qin, H.; Hong, S.; Li, H.; Lu, Y.; He, J.; Yang, J.; et al. Active vaccination with Dickkopf-1 induces protective and therapeutic antitumor immunity in murine multiple myeloma. Blood 2012, 119, 161-169. [CrossRef] [PubMed]

130. Pozzi, S.; Fulciniti, M.; Yan, H.; Vallet, S.; Eda, H.; Patel, K.; Santo, L.; Cirstea, D.; Hideshima, T.; Schirtzinge, L.; et al. In vivo and in vitro effects of a novel anti-Dkk1 neutralizing antibody in multiple myeloma. Bone 2013, 53, 487-496. [CrossRef] [PubMed]

131. Heath, D.J.; Chantry, A.D.; Buckle, C.H.; Coulton, L.; Shaughnessy, J.D.; Evans, H.R.; Snowden, J.A.; Stover, D.R.; Vanderkerken, K.; Croucher, P.I. Inhibiting Dickkopf-1 (Dkk1) Removes Suppression of Bone Formation and Prevents the Development of Osteolytic Bone Disease in Multiple Myeloma. J. Bone Miner. Res. 2008, 24, 425-436. [CrossRef] [PubMed]

132. Munshi, N.C.; Abonour, R.; Beck, J.T.; Bensinger, W.; Facon, T.; Stockerl-Goldstein, K.; Baz, R.; Siegel, D.S.; Neben, K.; Lonial, S.; Suvannasankha, A.; et al. Early Evidence of Anabolic Bone Activity of BHQ880, a Fully Human Anti-DKK1 Neutralizing Antibody: Results of a Phase 2 Study in Previously Untreated Patients with Smoldering Multiple Myeloma at Risk for Progression. Blood 2012, 120, 331.

133. Iyer, S.P.; Beck, J.T.; Stewart, A.K.; Shah, J.; Kelly, K.R.; Isaacs, R.; Bilic, S.; Sen, S.; Munshi, N.C. A Phase IB multicentre dose-determination study of BHQ880 in combination with anti-myeloma therapy and zoledronic acid in patients with relapsed or refractory multiple myeloma and prior skeletal-related events. Br. J. Haematol. 2014, 167, 366-375. [CrossRef] [PubMed]

134. Cosman, F.; Crittenden, D.B.; Adachi, J.D.; Binkley, N.; Czerwinski, E.; Ferrari, S.; Hofbauer, L.C.; Lau, E.; Lewiecki, E.M.; Miyauchi, A.; et al. Romosozumab Treatment in Postmenopausal Women with Osteoporosis. N. Engl. J. Med. 2016, 375, 1532-1543. [CrossRef] [PubMed]

135. McDonald, M.M.; Reagan, M.R.; Youlten, S.E.; Mohanty, S.T.; Seckinger, A.; Terry, R.L.; Pettitt, J.A.; Simic, M.K.; Cheng, T.L.; Morse, A.; et al. Inhibiting the osteocyte-specific protein sclerostin increases bone mass and fracture resistance in multiple myeloma. Blood 2017, 129, 3452-3464. [CrossRef] [PubMed]

136. McDonald, M.M.; Delgado-Calle, J. Sclerostin: An Emerging Target for the Treatment of Cancer-Induced Bone Disease. Curr. Osteoporos. Rep. 2017, 15, 532-541. [CrossRef] [PubMed]

137. Raje, N.; Vallet, S. Sotatercept, a soluble activin receptor type 2A IgG-Fc fusion protein for the treatment of anemia and bone loss. Curr. Opin. Mol. Ther. 2010, 12, 586-597. [PubMed]

138. Abdulkadyrov, K.M.; Salogub, G.N.; Khuazheva, N.K.; Sherman, M.L.; Laadem, A.; Barger, R.; Knight, R.; Srinivasan, S.; Terpos, E. Sotatercept in patients with osteolytic lesions of multiple myeloma. Br. J. Haematol. 2014, 165, 814-823. [CrossRef] [PubMed]

139. Scullen, T.; Santo, L.; Vallet, S.; Fulciniti, M.; Eda, H.; Cirstea, D.; Patel, K.; Nemani, N.; Yee, A.; Mahindra, A.; et al. Lenalidomide in combination with an activin A-neutralizing antibody: Preclinical rationale for a novel anti-myeloma strategy. Leukemia 2013, 27, 1715-1721. [CrossRef] [PubMed]

140. Adamik, J.; Jin, S.; Sun, Q.; Zhang, P.; Weiss, K.R.; Anderson, J.L.; Silbermann, R.; Roodman, G.D.; Galson, D.L. EZH2 or HDAC1 Inhibition Reverses Multiple Myeloma-Induced Epigenetic Suppression of Osteoblast Differentiation. Mol. Cancer Res. 2017, 15, 405-417. [CrossRef] [PubMed]

141. Deleu, S.; Lemaire, M.; Arts, J.; Menu, E.; Van Valckenborgh, E.; King, P.; Vande Broek, I.; De Raeve, H.; Van Camp, B.; Croucher, P.; et al. The effects of JNJ-26481585, a novel hydroxamate-based histone deacetylase inhibitor, on the development of multiple myeloma in the 5T2MM and 5T33MM murine models. Leukemia 2009, 23, 1894-1903. [CrossRef] [PubMed]

142. Xu, S.; De Veirman, K.; Evans, H.; Santini, G.C.; Vande Broek, I.; Leleu, X.; De Becker, A.; Van Camp, B.; Croucher, P.; Vanderkerken, K.; et al. Effect of the HDAC inhibitor vorinostat on the osteogenic differentiation of mesenchymal stem cells in vitro and bone formation in vivo. Acta Pharmacol. Sin. 2013, 34, 699-709. [CrossRef] [PubMed]

143. Mirandola, L.; Apicella, L.; Colombo, M.; Yu, Y.; Berta, D.G.; Platonova, N.; Lazzari, E.; Lancellotti, M.; Bulfamante, G.; Cobos, E.; et al. Anti-Notch treatment prevents multiple myeloma cells localization to the bone marrow via the chemokine system CXCR4/SDF-1. Leukemia 2013, 27, 1558-1566. [CrossRef] [PubMed]

144. Schwarzer, R.; Nickel, N.; Godau, J.; Willie, B.M.; Duda, G.N.; Schwarzer, R.; Cirovic, B.; Leutz, A.; Manz, R.; Bogen, B.; et al. Notch pathway inhibition controls myeloma bone disease in the murine MOPC315.BM model. Blood Cancer J. 2014, 4, e217. [CrossRef] [PubMed] 
145. Wei, P.; Walls, M.; Qiu, M.; Ding, R.; Denlinger, R.H.; Wong, A.; Tsaparikos, K.; Jani, J.P.; Hosea, N.; Sands, M.; et al. Evaluation of Selective Gamma-Secretase Inhibitor PF-03084014 for Its Antitumor Efficacy and Gastrointestinal Safety to Guide Optimal Clinical Trial Design. Mol. Cancer Ther. 2010, 9, 1618-1628. [CrossRef] [PubMed]

146. Krop, I.; Demuth, T.; Guthrie, T.; Wen, P.Y.; Mason, W.P.; Chinnaiyan, P.; Butowski, N.; Groves, M.D.; Kesari, S.; Freedman, S.J.; et al. Phase I pharmacologic and pharmacodynamic study of the gamma secretase (Notch) inhibitor MK-0752 in adult patients with advanced solid tumors. J. Clin. Oncol. 2012, 30, 2307-2313. [CrossRef] [PubMed]

147. Wu, Y.; Cain-Hom, C.; Choy, L.; Hagenbeek, T.J.; De Leon, G.P.; Chen, Y.; Finkle, D.; Venook, R.; Wu, X.; Ridgway, J.; et al. Therapeutic antibody targeting of individual Notch receptors. Nature 2010, 464, 1052-1057. [CrossRef] [PubMed]

148. Chiorean, E.G.; LoRusso, P.; Strother, R.M.; Diamond, J.R.; Younger, A.; Messersmith, W.A.; Adriaens, L.; Liu, L.; Kao, R.J.; DiCioccio, A.T.; et al. A phase I first-in-human study of enoticumab (REGN421), a fully human delta-like ligand 4 (Dll4) monoclonal antibody in patients with advanced solid tumors. Clin. Cancer Res. 2015, 21, 2695-2703. [CrossRef] [PubMed]

149. Vallet, S.; Anderson, K.C. CCR1 as a target for multiple myeloma. Expert Opin. Ther. Targets 2011, 15, 1037-1047. [CrossRef] [PubMed]

150. Menu, E.; De Leenheer, E.; De Raeve, H.; Coulton, L.; Imanishi, T.; Miyashita, K.; Van Valckenborgh, E.; Van Riet, I.; Van Camp, B.; Horuk, R.; et al. Role of CCR1 and CCR5 in homing and growth of multiple myeloma and in the development of osteolytic lesions: A study in the 5TMM model. Clin. Exp Metastasis 2006, 23, 291-300. [CrossRef] [PubMed]

151. Prabhala, R.H.; Fulciniti, M.; Pelluru, D.; Rashid, N.; Nigroiu, A.; Nanjappa, P.; Pai, C.; Lee, S.; Prabhala, N.S.; Bandi, R.L.; et al. Targeting IL-17A in multiple myeloma: A potential novel therapeutic approach in myeloma. Leukemia 2016, 30, 379-389. [CrossRef] [PubMed]

152. Fulciniti, M.; Hideshima, T.; Vermot-Desroches, C.; Pozzi, S.; Nanjappa, P.; Shen, Z.; Patel, N.; Smith, E.S.; Wang, W.; Prabhala, R.; et al. A high-affinity fully human anti-IL-6 mAb, 1339, for the treatment of multiple myeloma. Clin. Cancer Res. 2009, 15, 7144-7152. [CrossRef] [PubMed]

153. Tai, Y.T.; Chang, B.Y.; Kong, S.Y.; Fulciniti, M.; Yang, G.; Calle, Y.; Hu, Y.; Lin, J.; Zhao, J.J.; Cagnetta, A.; et al. Bruton tyrosine kinase inhibition is a novel therapeutic strategy targeting tumor in the bone marrow microenvironment in multiple myeloma. Blood 2012, 120, 1877-1887. [CrossRef] [PubMed]

154. Hiasa, M.; Teramachi, J.; Oda, A.; Amachi, R.; Harada, T.; Nakamura, S.; Miki, H.; Fujii, S.; Kagawa, K.; Watanabe, K.; et al. Pim-2 kinase is an important target of treatment for tumor progression and bone loss in myeloma. Leukemia 2015, 29, 207-217. [CrossRef] [PubMed] 